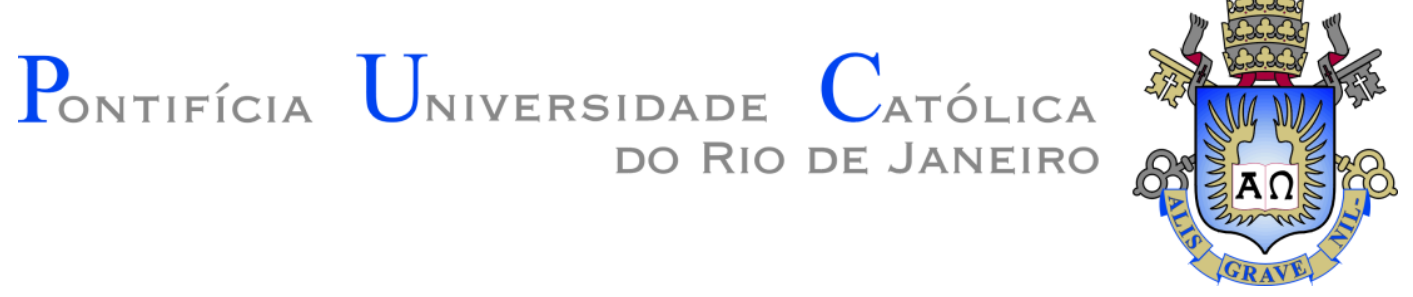

Rodrigo José Abreu dos Santos

A relação entre a matemática e a fotografia

Dissertação de Mestrado

Dissertação apresentada como requisito parcial para obtenção do grau de Mestre em Matemática pelo Programa de Pós-Graduação em Matemática, do Departamento de Matemática da PUC-Rio.

Orientador: Prof. Marcos Craizer

Rio de Janeiro, março de 2021 
Rodrigo José Abreu dos Santos

\section{A relação entre a matemática e a fotografia}

Dissertação apresentada como requisito parcial para obtenção do grau de Mestre pelo Programa de PósGraduação em Matemática da PUC-Rio. Aprovada pela Comissão Examinadora abaixo:

Prof. Marcos Craizer

Orientador

Departamento de Matemática - PUC-Rio

Profa. Christine Sertã Costa

Departamento de Matemática - PUC-Rio

Profa. Renata Martins da Rosa

Departamento de Matemática - PUC-Rio

Profa. Gabriela dos Santos Barbosa Fundação Educacional Unificada Campograndense 
Todos os direitos reservados. A reprodução, total ou parcial, do trabalho é proibida sem autorização da universidade, do autor e do orientador.

Rodrigo José Abreu dos Santos

Graduou-se em Matemática na Fundação Educacional Unificada Campograndense em 2005. Conclui a Pós-Graduação (Lato Sensu) em Matemática para o Ensino Fundamental e Médio em 2007. Participou no Instituto de Matemática Pura e Aplicada do Curso de Aperfeiçoamento para Professores de Matemática do Ensino Médio em 2007 e 2008. Lecionou na Pós-Graduação de Matemática na Fundação Educacional Unificada Campograndense entre 2010 e 2018. Atualmente leciona na Prefeitura da Cidade do Rio de Janeiro. Foi responsável por ministrar formações pedagógicas e de novas tecnologias para professores, coordenadores pedagógicos e diretores de todas as Unidades Escolares durante 2 anos no âmbito da $10^{\mathrm{a}}$ Coordenadoria Regional de Educação, sendo gerente da Assessoria de Tecnologias na Educação. Produziu o material de Matemática para a plataforma Educopédia, utilizada pelos professores em sala de aula. Atua como um dos responsáveis pelo Rioeduca, plataforma da Secretaria Municipal de Educação, que publica postagens sobre as atividades e projetos das Unidades Escolares. Assessorou durante 4 anos a Coordenadora da $10^{\mathrm{a}}$ Coordenadoria Regional de Educação da Prefeitura Municipal do Rio de Janeiro, cuidando da parte administrativa de todas as Unidades Escolares. Ajudou na organização territorial para a construção de 40 novas unidades escolares para a $10^{\text {a }}$ Coordenadoria Regional de Educação para alcançar 35\% dos alunos em tempo integral em 2016.

Ficha Catalográfica

Santos, Rodrigo José Abreu dos

A relação entre a matemática e a fotografia / Rodrigo José Abreu dos Santos ; orientador: Marcos Craizer. 2021.

61 f. : il. color. ; $30 \mathrm{~cm}$

Dissertação (mestrado)-Pontifícia Universidade Católica do Rio de Janeiro, Departamento de Matemática, 2021. Inclui bibliografia

1. Matemática - Teses. 2. Matemática. 3. Fotografia. 4. Tecnologia. 5. Ensino. 6. Aprendizagem. I. Craizer, Marcos. II. Pontifícia Universidade Católica do Rio de Janeiro. Departamento de Matemática. III. Título. 


\section{Agradecimentos}

Ao meu orientador Professor Marcos Craizer pelo estímulo e parceria para a realização deste trabalho.

Ao CNPq e à PUC-Rio, pelos auxílios concedidos, sem os quais este trabalho não poderia ter sido realizado.

Aos meus amigos Anderson e Andreia por todo apoio e parceria.

Aos meus pais, pela educação, atenção e carinho de todas as horas.

Aos meus colegas da PUC-Rio.

Aos professores que participaram da Comissão Examinadora.

A todos os professores e funcionários do Departamento pelos ensinamentos e pela ajuda.

A todos os amigos e familiares que de forma ou de outra me estimularam ou me ajudaram.

O presente trabalho foi realizado com apoio da Coordenação de Aperfeiçoamento de Pessoal de Nível Superior - Brasil (CAPES) - Código de Financiamento 001. 


\section{Resumo}

Santos, Rodrigo José Abreu dos; Craizer, Marcos. A relação entre a Matemática e a fotografia. Rio de Janeiro, 2021. 61p. Dissertação de Mestrado - Departamento de Matemática, Pontifícia Universidade Católica do Rio de Janeiro.

Este trabalho tem o objetivo de apresentar a matemática presente na fotografia e, para isso, usamos a tecnologia e a comunicação através da fotografia, que fazem parte do cotidiano dos alunos. Começamos com um levantamento histórico sobre a fotografia, desde o seu surgimento no mundo e no Brasil, passando pela primeira fotografia colorida e a evolução das câmeras fotográficas. Em seguida, são apresentados conceitos matemáticos presentes na fotografia, tais como frações, área e diâmetro do círculo, sequência de Fibonacci, proporção áurea, regra do terço, distância focal, ângulo e perspectiva. A proposta apresentada defende o uso da tecnologia a favor do desenvolvimento de propostas pedagógicas que ajudem no processo de ensino e aprendizagem. Para finalizar, foi realizada uma pesquisa de campo com alunos do projeto Carioca I e Carioca II de uma escola da rede municipal de ensino do Rio de Janeiro. O trabalho fica como sugestão para que possa acontecer um projeto escolar envolvendo a Etnomatemática, ou seja, uma análise das práticas matemáticas na fotografia em seus diferentes contextos culturais nas diferentes formas de conhecimento, que, de modo geral, é uma maneira que cada grupo ou indivíduo tem de operacionalizar a Matemática. Além disso, pode ser explorada a parte da Interdisciplinaridade, uma vez que, a fotografia pode envolver as disciplinas de História, Geografia, Física, Artes, Matemática, entre outras.

\section{Palavras-Chave:}

Matemática; Fotografia; Tecnologia; Ensino; Aprendizagem. 


\section{Abstract}

Santos, Rodrigo José Abreu dos; Craizer, Marcos (Advisor). The relationship between mathematics and photography. Rio de Janeiro, 2021. 61p. Dissertação de Mestrado - Departamento de Matemática, Pontifícia Universidade Católica do Rio de Janeiro.

This work aims to present the mathematics present in photography and, for that, we use technology and communication through photography, which are part of the students' daily lives. We started with a historical survey of photography, since its emergence in the world and in Brazil, going through the first color photography and the evolution of cameras. Then, mathematical concepts present in the photograph are presented, such as fractions, area and diameter of the circle, Fibonacci sequence, golden ratio, rule of third, focal length, angle and perspective. The presented proposal defends the use of technology in favor of the development of pedagogical proposals that help in the teaching and learning process. Finally, a field research was carried out with students from the Carioca I and Carioca II project at a school in the municipal education system in Rio de Janeiro. The work is a suggestion for a school project involving Ethnomathematics to take place, that is, an analysis of mathematical practices in photography in their different cultural contexts in different forms of knowledge, which, in general, is a way that each group or individual has to operationalize mathematics. In addition, the Interdisciplinarity part can be explored, since photography can involve the disciplines of History, Geography, Physics, Arts, Mathematics, among others.

\section{Keywords:}

Mathematics; Photography; Technology; Teaching; Learning. 


\section{Sumário}

$\begin{array}{ll}\text { 1. Introdução } & 12\end{array}$

2. A história da fotografia 14

2.1 O que é fotografia? 14

2.2 O surgimento da fotografia 14

$\begin{array}{ll}2.3 \text { A fotografia colorida } & 17\end{array}$

2.4 O surgimento da fotografia no Brasil 19

2.5 Evolução da fotografia 20

2.6 Câmera fotográfica 25

3. A matemática na fotografia 30

3.1 As frações e a velocidade do obturado 30

3.2 A área do círculo e o diâmetro (abertura) da lente 33

3.3 A sequência de Fibonacci e a proporção áurea 36

3.4 Conversão da sequência de Fibonacci para razão áurea 42

3.5 A regra do terço 43

3.6 Distância focal e ângulo de visão das objetivas 46

3.7 A perspectiva e a ilusão de ótica na fotografia 47

4. Pesquisa de campo 51

4.1 Apresentação do projeto aos alunos 51

4.2 Resultados 52

4.3 Fotografias dos alunos 53

5. Considerações finais 60

6. Referências bibliográficas 61 


\section{Lista de Tabelas}

Tabela 1 - Divisão de um número de Fibonacci por seu antecessor 


\section{Lista de figuras}

Figura 1 - Primeira fotografia reconhecida $\quad 14$

$\begin{array}{ll}\text { Figura } 2 \text { - Daguerreótipo } & 16\end{array}$

Figura 3 - Imagem obtida através do calótipo: o negativo, à esquerda e o positivo, à direita

Figura 4 - Primeira fotografia colorida tirada por James Clerk Maxwell em $1861 \quad 17$

Figura 5 - Fotografia feita por DucosduHauron, em Agen, em 1877

Figura 6 - Paço Imperial por Louis Compte em $1840 \quad 20$

Figura 7 - Câmera panorâmica Al Vista - 1900

Figura 8 - Brownie-Kodak - 1901

Figura 9 - Kodak 4 "Screen Focus" Modelo A - 1904

Figura 10 - Câmera TouristMultiple - 1913

Figura 11 - Câmera Cosmos 35 - 1922 e câmera Sico - 1923

Figura 12 - Câmera fotográfica MAMIYA 6 - 1940

Figura 13 - Câmera - $1960 \quad 24$

Figura 14 - Gmtex GT - 304-1985 24

Figura 15 - Câmera Sony - 2000

Figura 16 - Câmera Semiprofissional Canon - 2010

Figura 17 - Gopro 25

Figura 18 - Drone $\quad 25$

Figura 19 - Comparação da câmera fotográfica com o olho humano 26

Figura 20 - Funcionamento da câmera fotográfica 26

Figura 21 - Elementos de uma câmera fotográfica $\quad 27$

Figura 22 - Fotografias com velocidade de obturador diferente 31

Figura 23 - Atleta correndo 32

Figura 24 - Diferentes valores da velocidade do obturador para fotografias de um cata-vento

Figura 25 - Ponto (f-stop) do obturador 33

Figura 26 - Abertura do diafragma 35

Figura 27 - Diferentes quantidades de passagem de luz 35

Figura 28 - Divisão seguindo a proporção áurea 36 
Figura 29 - Proporção áurea $\quad 37$

Figura 30 - Proporção áurea e a sequência de Fibonacci 37

Figura 31 - Proporção áurea: Monalisa 38

Figura 32 - Fotografia usando grade 38

Figura 33 - Proporção áurea entre a e b 39

Figura 34 - Proporção áurea: Girassol 40

Figura 35 - Proporção áurea: Caracol 40

Figura 36 - Proporção áurea: Partenon $\quad 41$

Figura 37 - Linhas imaginárias para regra dos terços $\quad 44$

Figura 38 - Fotografia utilizando a regra dos terços $\quad 45$

Figura 39 - Fotografia utilizando a regra dos terços 45

Figura 40 - Distância focal 46

Figura 41 - Lentes e distâncias focais $\quad 46$

Figura 42 - llusão de ótica $\quad 49$

Figura 43 - llusão de ótica $\quad 49$

Figura 44 - llusão de ótica $\quad 50$

Figura 45 - llusão de ótica $\quad 50$

Figura 46 - llusão de ótica $\quad 50$

Figura 47 - Foto do aluno A da turma 7102

Figura 48 - Foto do aluno B da turma 7102

Figura 49 - Foto do aluno $C$ da turma 7102

Figura 50 - Foto do aluno D da turma 7101

Figura 51 - Foto do aluno E da turma 7102

Figura 52 - Foto do aluno F da turma 7102

Figura 53 - Foto do aluno G da turma 1903

Figura 54 - Foto do aluno H da turma 7101

Figura 55 - Foto do aluno I da turma 1903

Figura 56 - Foto do aluno $\mathrm{J}$ da turma 7101

Figura 57 - Foto do aluno K da turma 7201 


\section{1 \\ Introdução}

Muitos alunos nos questionam sobre aplicações dos conteúdos matemáticos aprendidos na escola. Eles querem saber onde irão ver a Matemática propriamente dita no dia a dia. Com isso, contextualizações são necessárias para que o conteúdo explicado possa fazer sentido para o aluno, saindo do abstrato para o concreto. Nos dias atuais, o professor precisa ser inovador, dinâmico e saber trabalhar com propostas que instiguem os alunos, criando o interesse e chamando a atenção. Sendo assim, a escolha de trabalhar conteúdos matemáticos aliados à fotografia é com o intuito de despertar curiosidade nos alunos e vontade de aprender a disciplina que causa tanto pavor em boa parte dos alunos. A proposta deste trabalho teve como objetivo abordar um pouco da história da fotografia, passando pelos inventores, tipos de máquinas, mostrando que na fotografia podemos encontrar conceitos de fração, área do círculo, sequência de Fibonacci, perspectiva, razão áurea, entre outros. Para isso, procuramos juntar a fotografia às atividades matemáticas estabelecidas, proporcionando uma conexão com o cotidiano do aluno, já que a fotografia está cada vez mais presente na vida do ser humano. Muitas vezes os alunos necessitam de algo concreto para entender o porquê do objeto de estudo, facilitando a vida do aluno e, dessa forma, o processo de ensino aprendizagem se torna mais prazeroso e ao mesmo tempo interessante e motivador. Vale ressaltar que razão áurea e sequência de Fibonacci não são conteúdos obrigatórios no currículo do ensino fundamental, mas podem ser estudados de forma atrativa e bem conectados com outros assuntos, como razão e proporção, por exemplo.

Acreditamos que o professor precisa saber que o processo de informatização da sociedade já chegou às escolas. O celular, por exemplo, pode ser uma ferramenta de grande auxílio a prática educacional. O professor, o aluno e a informática devem ser aliados e buscar resultados positivos em conjunto para o processo de ensino e aprendizagem. O docente pode realizar com seus alunos vários tipos de atividades individuais ou em grupos desenvolvendo o espírito cooperativo, incentivando a criatividade, exercitando o pensamento lógico e estimulando inúmeras outras capacidades com o auxílio da tecnologia. 
Já que a Matemática está presente em várias áreas não exatas e muitas pessoas desconhecem tal informação, a ideia deste trabalho é mostrar a Matemática presente na fotografia e, com isso, despertar o interesse dos alunos. Vale ressaltar que, o uso de tecnologias também pode ajudar o professor no momento da preparação da aula. Hoje em dia, a maioria dos alunos possui celular e contas em redes sociais, por isso o professor deve aproveitar esse fator a seu favor, unindo suas atividades com os recursos tecnológicos disponíveis. Desta maneira, usar fotografia para ensinar Matemática pode contribuir significativamente nos resultados de aprendizagem. Nos capítulos seguintes, apresentaremos a história e a origem da fotografia, a fotografia colorida, a fotografia no Brasil, a evolução da fotografia até os dias atuais, as frações e a velocidade do obturador, área do círculo e a abertura do diafragma da lente, sequência de Fibonacci, distância focal e o ângulo de visão das objetivas, perspectiva, razão áurea, retângulo áureo e espiral áureo. Posteriormente, apresentaremos uma pesquisa de campo com alunos da Prefeitura da Cidade do Rio de Janeiro. 


\section{2}

\section{A história da fotografia}

\section{1. \\ 0 que é fotografia?}

Segundo o dicionário, fotografia é a arte ou processo de reproduzir imagens sobre uma superfície fotossensível, pela ação de energia radiante, especialmente a luz e, por metonímia, podemos afirmar que é a imagem obtida por esse processo; foto, retrato. Ou seja, é essencialmente a técnica de criação de imagens por meio de exposição luminosa, fixando-as em uma superfície sensível.

\section{2.}

\section{O surgimento da fotografia}

A primeira fotografia reconhecida foi registrada em 1826 (vide figura 1), pelo francês Joseph Nicéphore Niépce (1765-1833), porém, podemos afirmar que a fotografia não é obra final de um único criador, pois diversas descobertas ao longo dos anos foram acontecendo e, com isso, agregando conceitos e processos para que fosse possível desenvolver a fotografia como é conhecida nos dias atuais.

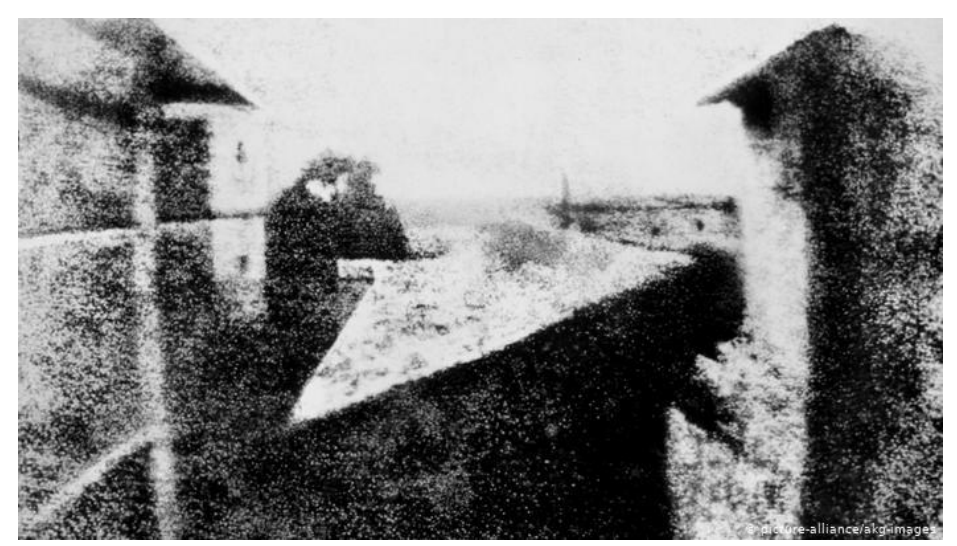

Figura 1 - Primeira fotografia reconhecida Fonte: https://static.dw.com/image/38763030_303.jpg

Muitos químicos e físicos foram um dos primeiros neste ramo, uma vez que os processos de revelação e da fixação da fotografia são basicamente físicoquímicos, numa associação de condições ambientais e de iluminação a produtos químicos. Vale ressaltar que, as primeiras experiências fotográficas de químicos datam de cerca 350 a.C. Porém, foi no século X que o árabe Alhaken de Basora 
descobriu como se formavam imagens no interior de sua tenda quando a luz do sol passava pelas frestas do tecido.

Segundo GARCIA (1982) em 1525 já se conhecia a técnica de escurecimento dos sais de prata. O conceito de câmera escura, descrito em 1558 por Giovanni Battista Della Porta (1535 - 1615), já era conhecido por Leonardo da Vinci (1452 - 1519) que, assim como muitos outros artistas do século XVI, usava a técnica para esboçar pinturas. Em 1604, o químico italiano Ângelo Sala (1576-1637) já tinha conhecimento que alguns compostos de prata oxidavam quando eram expostos ao sol. Além disso, o farmacêutico sueco Carl Wilhelm Scheele (17421786) contribuiu para esta descoberta em 1777, ao demonstrar o enegrecimento de sais expostos à ação da luz. Em 1725, o cientista alemão Johann Henrich Schulze (1687-1744) projetou uma imagem durável numa superfície. Em seguida, o químico britânico Thomas Wedgwood (1771-1805) realizou no início do século XIX experimentos semelhantes.

Todos esses acontecimentos anteriores foram importantes e contribuíram significativamente para o surgimento da fotografia e, em 1826, ocorreu o primeiro registro de uma fotografia, a qual foi feita numa placa de estanho coberta com um derivado de petróleo fotossensível chamado betume de Judéia, que é um mineral utilizado como escurecedor. A imagem foi produzida com uma câmera, ficando cerca de oito horas em exposição à luz solar. Niépce chamou o processo de heliografia, que significa gravura com a luz do sol. Quase que ao mesmo tempo, Louis Jacques Mandé Daguerre (1787-1851), produzia com uma câmera escura efeitos visuais em um espetáculo denominado "Diorama". Daguerre e Niépce trocaram correspondência durante alguns anos, até finalmente firmarem uma sociedade.

Quando Nièpce faleceu, Daguerre desenvolveu um processo denominado daguerreotipia que envolvia vapor de mercúrio e reduzia o tempo de revelação de horas para minutos. Daguerre descreveu seu processo à Academia de Ciências e Belas Artes, na França, e, logo depois, requereu a patente do seu invento na Inglaterra. A popularização dos daguerreótipos (vide figura 2) deu origem às especulações sobre o "fim da pintura", inspirando o Impressionismo. 


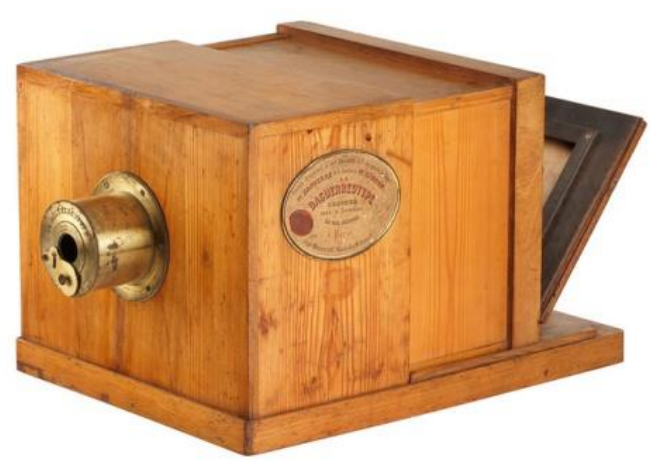

Figura 2 - Daguerreótipo Fonte: http://1.bp.blogspot.com/-

8jppae5HOqo/ToCEd8ME1JI/AAAAAAAACks/Z1I9NcTG6So/s500/Daguerreotipo.jpg

O dia da Fotografia é celebrado em 19 de agosto de 1839 quando o francês Louis Daguerre apresenta seu invento durante um encontro realizado no Instituto da França, em Paris, com a presença de membros da Academia de Ciências e da Academia de Belas-Artes. O cientista François Arago, secretário da Academia de Ciências, comunicou durante o evento que o governo francês havia adquirido o invento, colocando-o em domínio público e, dessa forma, fazendo com que o "mundo inteiro" tivesse acesso à invenção. Em troca, Louis Daguerre e o filho de Joseph Niépce, Isidore, passaram a receber uma pensão anual vitalícia do governo da França, de seis mil e quatro mil francos, respectivamente.

William Fox Talbot (1800 - 1877), que efetuava pesquisas com papéis fotossensíveis, ao tomar conhecimento, em 1839, das descobertas de Daguerre decidiu apressar a apresentação de seus trabalhos à Royal Institution e à Royal Society, para garantir os direitos sobre suas invenções. Ele desenvolveu um processo denominado calótipo, que usava folhas de papel cobertas com cloreto de prata, que posteriormente eram colocadas em contato com outro papel, produzindo a imagem positiva (vide figura 3). Este processo é muito parecido com o processo fotográfico usado atualmente, pois também produz um negativo que pode ser reutilizado para produzir várias imagens positivas. Nesse mesmo período, Hippolyte Bayard (1801-1887) também desenvolveu um método de fotografia. Porém, por demorar a anunciá-lo, não conseguiu ser reconhecido como seu inventor. 


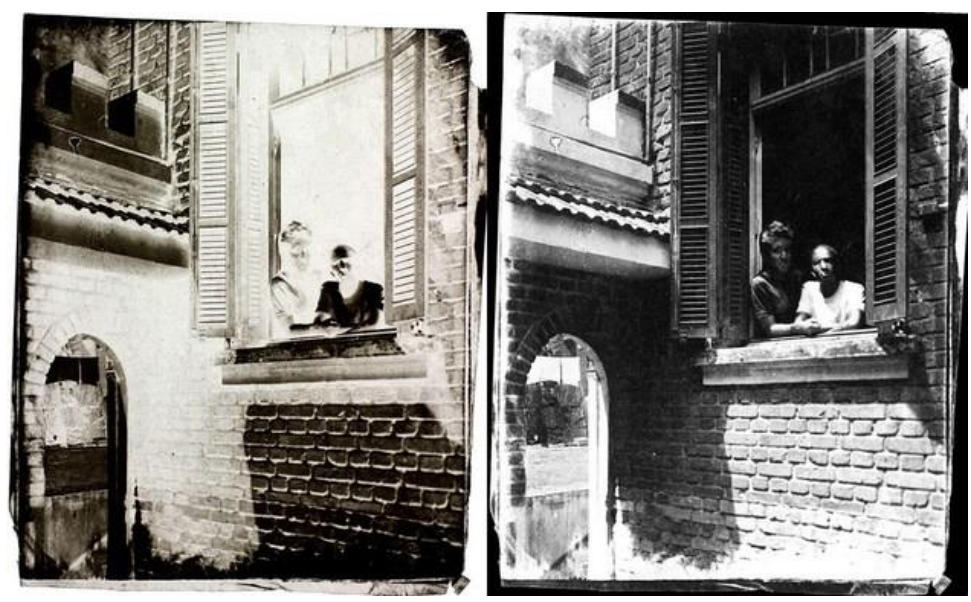

Figura 3 - Imagem obtida através do calótipo: o negativo, à esquerda e o positivo, à direita Fonte: https://miro.medium.com/max/1868/1*MdWPnc2LVWnTIdMbqWkUwA.png

\section{3.}

\section{A fotografia colorida}

A primeira fotografia colorida foi criada em 1861 (vide figura 4), pelo físico escocês James Clerk Maxwell (1831-1879) com ajuda do seu assistente Thomas Sutton (1819-1875). Eles realizavam estudos sobre como o olho humano percebe as cores. Baseando-se neles, utilizaram as técnicas já existentes da fotografia em preto e branco para tirar três fotos idênticas do mesmo objeto, cada uma através de um filtro diferente: vermelho, verde e azul. Depois, usando lâmpadas com filtros das mesmas cores usadas na captação, projetaram alinhadamente os resultados numa tela. A imagem gerada era colorida.

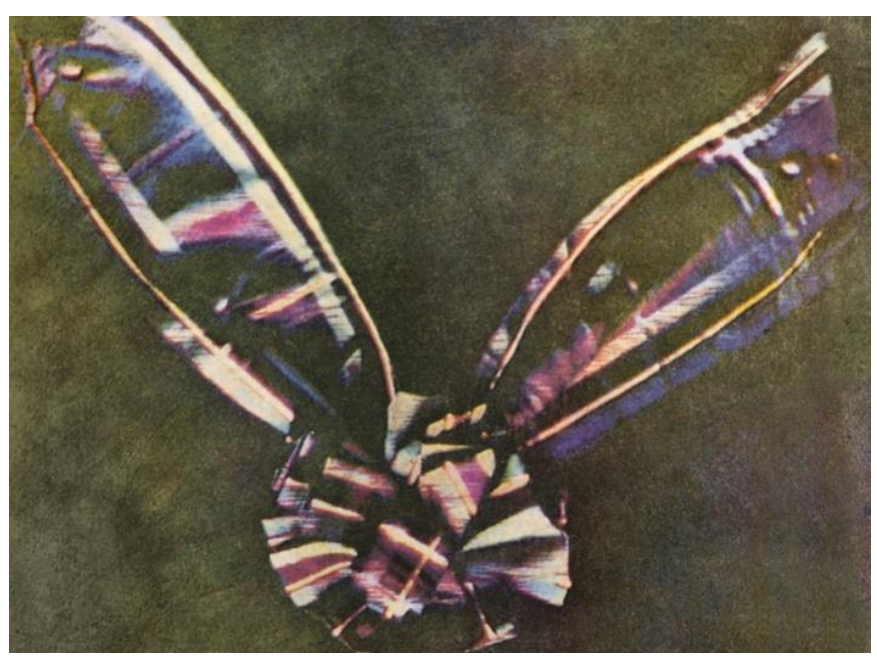

Figura 4 - Primeira fotografia colorida tirada por James Clerk Maxwell em 1861 Fonte: https://super.abril.com.br/wpcontent/uploads/2018/07/56745d8682bee174ca0445a5primeira-foto1.jpeg 
A técnica do escocês tinha algumas falhas, como uma captação muito maior do azul que do verde e praticamente a inexistência do vermelho - o rosa que aparece na imagem é uma captação acidental do ultravioleta. Porém, esse método das três cores influencia a fotografia até hoje. Cabe ressaltar que a tecnologia RGB, abreviatura de um sistema de cores aditivas em que o Vermelho (Red), o Verde (Green) e o Azul (Blue) que são combinados de várias formas de modo a reproduzir um largo espectro cromático, é inspirada nele. O propósito principal do sistema RGB é a reprodução de cores em dispositivos eletrônicos como monitores de TV e computadores, retroprojetores, scanners e câmeras digitais.

Porém, James Clerk Maxwell não estava sozinho nesse processo, Gabriel Lippman (1845-1921), Auguste Lumière (1862-1954) e Louis Lumière (18641948) contribuíram muito nesse processo. Posteriormente, Auguste Lumière e Louis Lumière conseguiriam colocar as imagens em movimento, fato que daria origem ao cinema. Por fim, o francês Ducos du Hauron (1837-1920) desenvolveu uma forma de imprimir três negativos com filtros coloridos em vermelho e azul. Em 1868 ele patenteou alguns de seus métodos e no ano seguinte escreveu Les Couleurs en Photographie. Um de seus primeiros trabalhos com fotografias coloridas foi Landscape of Southern France, tirada através do método subtrativo em 1877 (vide figura 5).

Em 1871, o método de emulsão seca de brometo de prata em colódio foi aperfeiçoado pelo médico inglês Richard Leach Maddox (1816-1902), que substituiu o colódio por placas secas de gelatina. Em 1877 Ducos du Hauron

A fotografia colorida pode formar imagens como uma transparência positiva, planejada para uso em projetor de diapositivos ou em negativos coloridos, planejado para uso de ampliações coloridas positivas em papel de revestimento especial. A última é atualmente a forma mais comum de filme fotográfico colorido (não digital), devido à introdução do equipamento de foto impressão automático. 


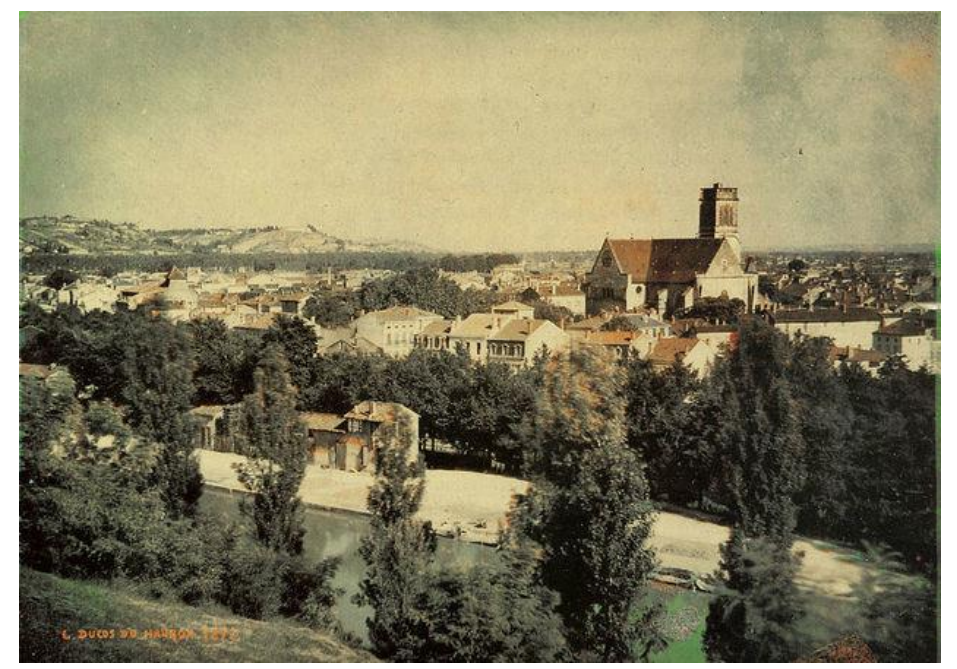

Figura 5 - Fotografia feita por Ducos du Hauron, em Agen, em 1877 Fonte: https://static.todamateria.com.br/upload/fo/to/fotografiacoloridabb-cke.jpg

\section{4. \\ O surgimento da fotografia no Brasil}

Segundo KOSSOY (1980) enquanto Daguerre realizava seus experimentos na Europa, outro francês, radicado em Campinas (São Paulo), buscava fixar as imagens numa superfície. Tratava-se de Antoine Hercule Romuald Florence (1804-1879), um viajante que participou da expedição científica de Langsdorff e que decidiu morar no Brasil. Florence utilizou, inclusive, a palavra "fotografia" em 1832, bem antes que muitos dos seus colegas europeus. Desta maneira, temos que a fotografia não foi uma invenção isolada, mas fruto de vários pesquisadores, que perseguiam o mesmo objetivo ao mesmo tempo. Porém, de forma oficial, a fotografia chega ao Brasil somente em 1840, um ano após a apresentação oficial do daguerreótipo na França.

O francês Louis Compte (1798-1868), que registrou umas das primeiras fotografias no Brasil (vide figura 6), fez demonstrações sobre o daguerreótipo ao imperador Dom Pedro II, que ficou encantado e passou a colecionar o objeto. Dom Pedro II posava com muita freqüência para retratos e, inclusive, tinha diversos fotógrafos oficiais, que deixaram muitos registros da família imperial e do Brasil que são usados hoje em dia como parte da história do nosso país. Ele era considerado o maior colecionador de fotografias do século XIX, mas não levou sua coleção para o exílio e doou mais de 25 mil imagens à Biblioteca Nacional, com a condição de que o conjunto levasse o nome da Imperatriz Teresa Cristina. 


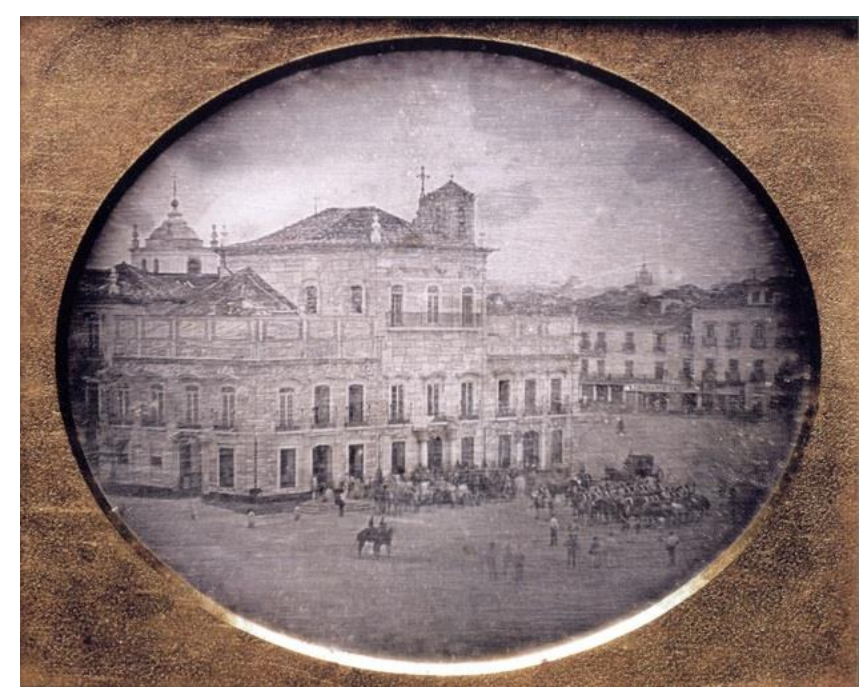

Figura 6 - Paço Imperial por Louis Compte em 1840 é uma das primeiras realizadas no Brasil Fonte: https://upload.wikimedia.org/wikipedia/commons/a/ad/Pa\%C3\%A7o_imperial_1840.jpg

A partir da urbanização e do crescimento das grandes cidades, a fotografia ganha seu espaço na sociedade brasileira. Podemos citar como referência profissional do século XIX, o fotógrafo Marc Ferrez (1843-1923) que realizou inúmeros registros fotográficos. Além disso, a fotografia serviu para deixar registrados momentos dramáticos como a Guerra do Paraguai (1865-1870) e a Guerra de Canudos (1895), conflitos que foram registrados pelo fotógrafo Flávio de Barros.

\section{5. Evolução da Fotografia}

Com o passar do tempo a forma de fazer fotografia não mudou, porém os avanços tecnológicos permitiram cada vez mais aprimorar a qualidade, aumentar a resolução e a realidade das cores. A busca pela acessibilidade da fotografia também era grande preocupação desde seu surgimento. A busca era intensa por materiais duráveis, eficazes, de baixo custo e pela aceleração no processo de revelação.

Após 1900, a aventura da fotografia prosseguiu com a consolidação e aperfeiçoamento das técnicas e equipamentos inventados durante o século anterior. Os aparelhos eram suficientemente pequenos, portáteis e acessíveis, mas ainda bastante diferentes das modernas câmeras fotográficas. Foi durante as duas primeiras décadas do século XX que inventaram técnicas e formatos dominantes que duraram até ao surgimento da fotografia digital: os filmes em película de celulóide de 
$35 \mathrm{~mm}$, as emulsões a cores, o sistema reflex e as câmeras fotográficas de corpo metálico.

Apesar de no Congresso de Paris de 1889 terem normalizado os formatos das chapas, as aberturas das objetivas e as velocidades de obturação, ainda era possível encontrar à venda numerosos formatos de películas fotográficas. Alguns fabricantes faziam questão de usar formatos próprios, que eram patenteados. As chapas de $6 \times 6 \mathrm{~cm}$ ou $6 \times 9 \mathrm{~cm}$, por exemplo, eram muito comuns, mas tinham o inconveniente da necessidade de serem colocadas uma a uma, o que tornava o processo de fotografar bastante lento e, além disso, limitava o tamanho das câmeras.

O desenvolvimento da fotografia colorida foi também um processo lento e que necessitou de muitos testes. O primeiro filme colorido foi produzido em 1907, mas ainda hoje a fotografia colorida não alcançou a definição da escala de tons que a sensibilidade do filme preto e branco possui.

A fotografia popularizou-se como produto de consumo a partir de 1888 , quando a empresa Kodak abriu as portas com um discurso de marketing onde todos podiam tirar suas fotos, sem necessitar de fotógrafos profissionais com a introdução da câmera tipo "caixão" e pelo filme em rolos substituíveis criados por George (1854-1932). Com isso, o mercado fotográfico obteve uma gigante evolução tecnológica, como o estabelecimento do filme colorido como padrão e o foco automático. Essas inovações facilitam a captação da imagem, melhoram a qualidade de reprodução ou a rapidez do processamento, mas pouco foi alterado nos princípios básicos da fotografia.

A maior mudança produzida a partir do final do século XX foi a digitalização dos sistemas fotográficos, que mudou o mundo da fotografia, diminuindo muito os custos e as etapas do processo, além de facilitar a produção, a manipulação, o armazenamento e a transmissão de imagens entre as pessoas. O aperfeiçoamento da tecnologia de reprodução de imagens digitais tem quebrado barreiras de restrição em relação a este sistema, ampliando o domínio da fotografia digital no mundo todo.

Com a fotografia digital, muitos paradigmas fotográficos foram alterados. Com o tempo foram surgindo aparelhos cada vez menores, mais simples de manipular, transportar e que produzem fotografias em altíssima qualidade e como a 
internet facilitou o fluxo das imagens, a fotografia tornou-se algo muito mais simples e popular do que antes, entrando de vez no gosto da população mundial. Hoje em dia já faz parte do cotidiano humano, pois permite guardar um momento para sempre.

A fotografia, logo que surgiu, não era considerada arte, e ainda existe até hoje opiniões divergentes quanto a isso. Para alguns críticos, a fotografia não pode ser considerada arte por conta da facilidade que existe em produzi-la, no entanto, outros críticos acreditam que ela pode ser considerada como arte a partir do momento em que é uma interpretação da realidade, e não apenas uma cópia.

A fotografia é utilizada na medicina, no jornalismo e na ciência, para o desenvolvimento de vários estudos. $\mathrm{E}$, hoje em dia, faz parte da vida de praticamente todos os seres humanos, que podem capturar suas fotos com seus celulares e smartphones, a qualquer hora e a qualquer momento.

Vamos verificar a evolução das câmeras fotográficas (vide figuras 7 a 18):

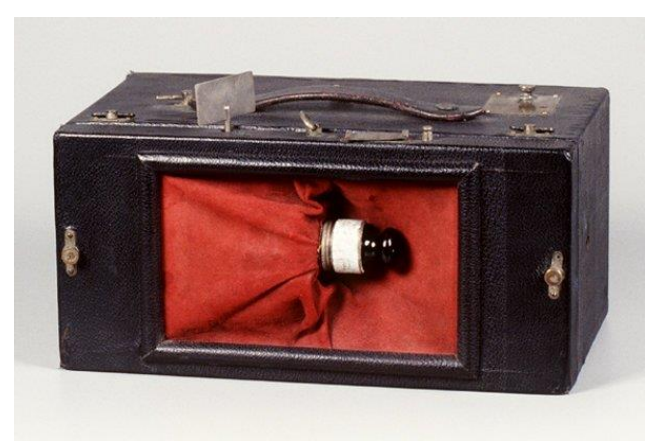

Figura 7 - Câmera panorâmica Al Vista - 1900

Fonte: http://obviousmag.org/archives/uploads/2010/10021101_obviousmag.org_camera.jpg

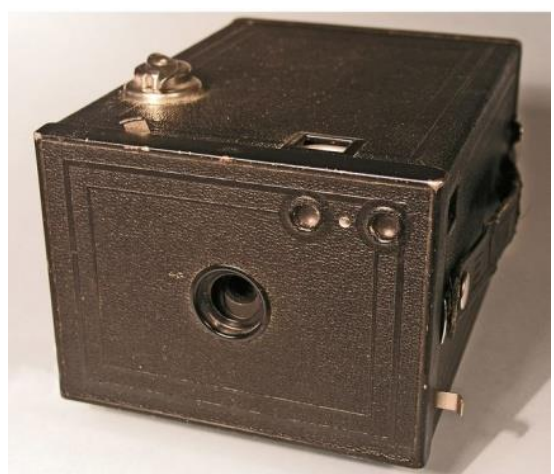

Figura 8 - Brownie-Kodak - 1901 Fonte:

https://upload.wikimedia.org/wikipedia/commons/thumb/f/f0/Brownie2_overview.jpg/220pxBrownie2_overview.jpg 


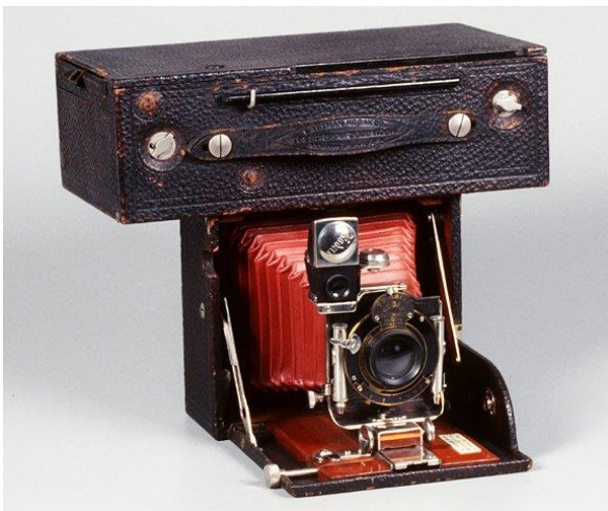

Figura 9 - Kodak 4 "Screen Focus" Modelo A - 1904

Fonte: http://obviousmag.org/archives/uploads/2010/10021105_obviousmag.org_camera.jpg

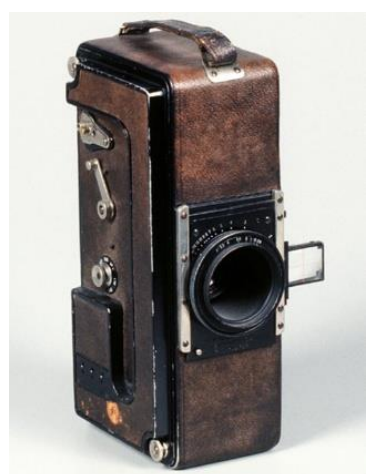

Figura 10 - Câmera TouristMultiple - 1913

Fonte: http://obviousmag.org/archives/uploads/2010/10021109_obviousmag.org_camera.jpg

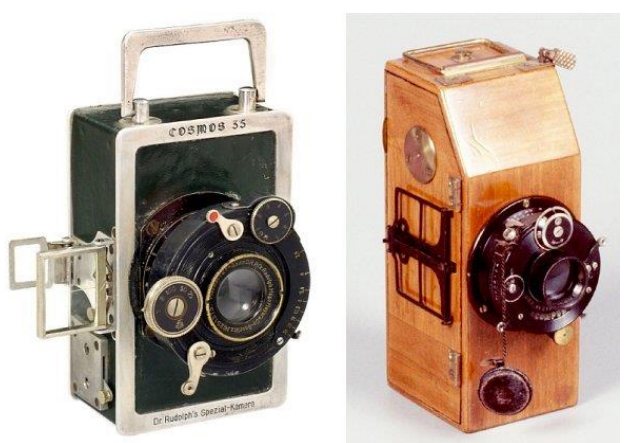

Figura 11 - Câmera Cosmos 35 - 1922 e câmera Sico - 1923

Fonte: http://obviousmag.org/archives/uploads/2010/10021114_obviousmag.org_camera.jpg

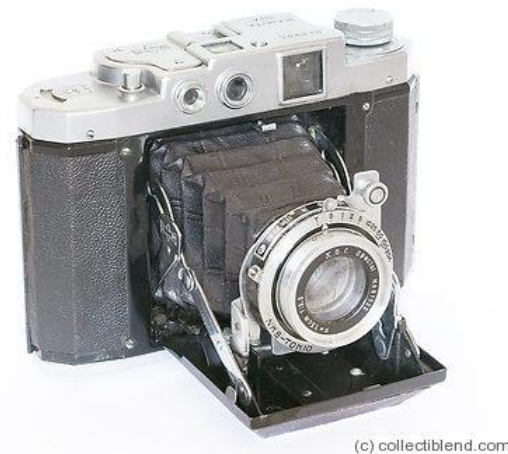

Figura 12 - Câmera fotográfica MAMIYA 6 - 1940

Fonte: https://collectiblend.com/Cameras/images/Mamiya-Mamiya-Six-I.jpg 


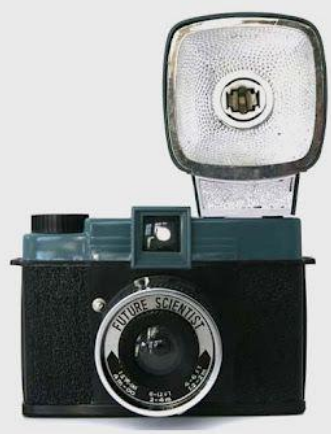

Figura 13 - Câmera - 1960

Fonte: https://i.pinimg.com/564x/ea/4f/7a/ea4f7a5653ddd64059a44af8c87c2581.jpg

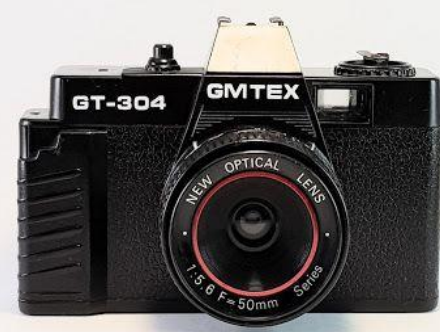

Figura 14 - Gmtex GT - $304-1985$

Fonte: https://i.pinimg.com/564x/8e/b7/cd/8eb7cda342351856e613dd0c0d357a72.jpg

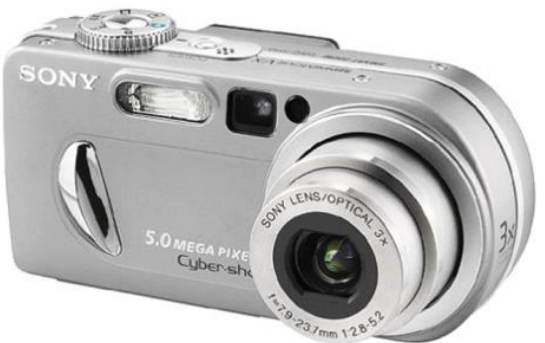

Figura 15 - Câmera Sony - 2000

Fonte: http://s2.glbimg.com/xWC54-

sCS6klRleuAWdmFxWvNok=/0x0:695x457/695x457/s.glbimg.com/po/tt2/f/original/2015/11/23/ cybershot_da_sony ficou_famoso_nos asnos 2000.png

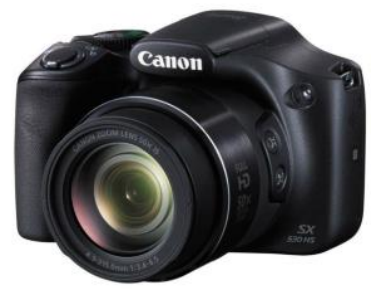

Figura 16 - Câmera Semiprofissional Canon - 2010

Fonte: https://s2.glbimg.com/ktCLC-

JfXEvkNWhu-

daQiFYb0sEQ=/0x0:1700x1100/984x0/smart/filters:strip icc()/i.s3.glbimg.com/v1/AUTH_08fbf4 8bc0524877943fe86e43087e7a/internal_photos/bs/2019/w/Y/Wvte2OQkSNTYsE8KkX3w/canonsx530-hs.jpg 


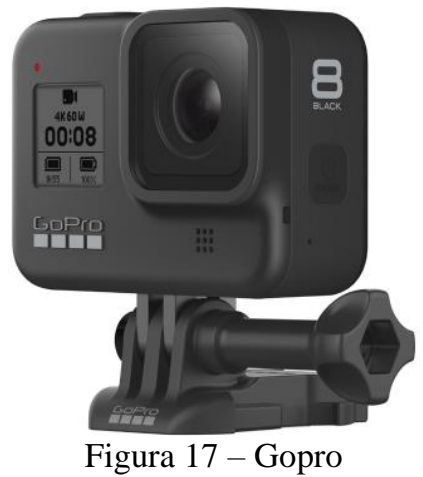

Fonte: https://images-submarino.b2w.io/produtos/01/00/img/1248693/5/1248693509_1SZ.jpg

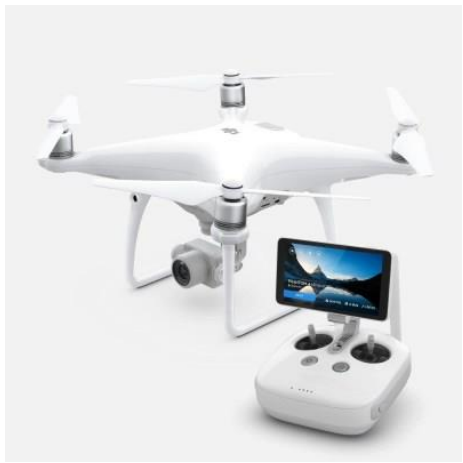

Figura 18 - Drone

Fonte: https://i0.wp.com/hire.empire.as/wp-content/uploads/2016/04/DJI-Phantom-4-AdvancedPlus.jpg?resize $=400 \% 2 \mathrm{C} 400 \&$ ssl $=1$

\section{6.}

\section{Câmera fotográfica}

A câmera fotográfica é um instrumento óptico para captação de imagens na forma de fotografias individuais, que podem ser arquivadas localmente, transmitidas para outro local, ou ambos. Como a câmera capta informações sobre elementos sem ter contato físico com eles, ela é tecnicamente classificada como um dispositivo de sensoriamento remoto.

A câmera é um dispositivo originalmente usado para projetar uma imagem sobre uma superfície plana. Sabe-se que mesmo com toda evolução das máquinas fotográficas, até mesmo os equipamentos mais modernos e mais sofisticados guardam seu princípio fundamental, uma caixa à prova de luz, com um orifício em um dos lados, que é bem parecido com o funcionamento do olho humano (vide figura 19). Por esse orifício entram raios de luz e, também, outras porções de espectro eletromagnético que são registrados em um filme fotográfico ou por um sensor de imagem. Além disso, as câmeras fotográficas contam com objetivas, obturadores e diafragmas, que controlam a quantidade de luz recebida; um sistema 
de foco, que permite ajustar a distância entre a objetiva e o filme ou sensor; e um visor, que auxilia na composição da cena que se quer fotografar.
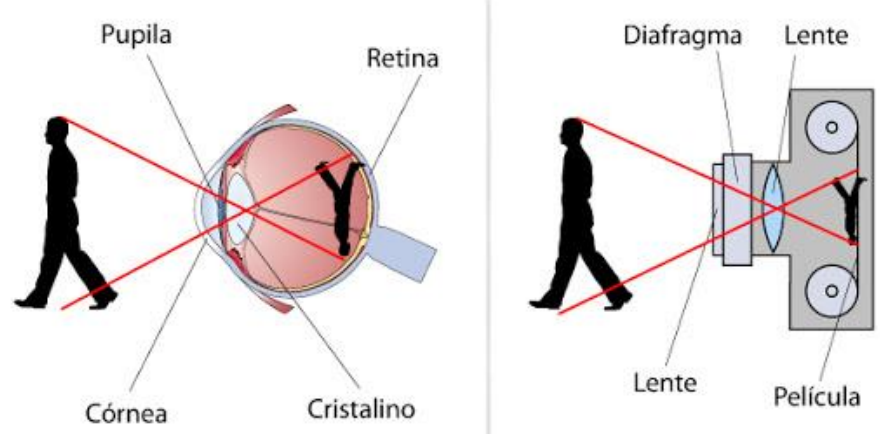

Figura 19 - Comparação da câmera fotográfica com o olho humano Fonte: http://leonardodavinci.cc/wp-content/uploads/2018/04/cerpo-oftalmologia.jpg

De forma bem simples podemos comparar uma máquina fotográfica com uma câmara escura de orifício (vide figura 20), porém, no lugar do orifício, é colocada uma lente convergente, ou seja, uma lente que converge para um único ponto os raios de luz que por ela atravessam. Na face oposta à da lente está fixado o filme fotográfico sensível à luz.

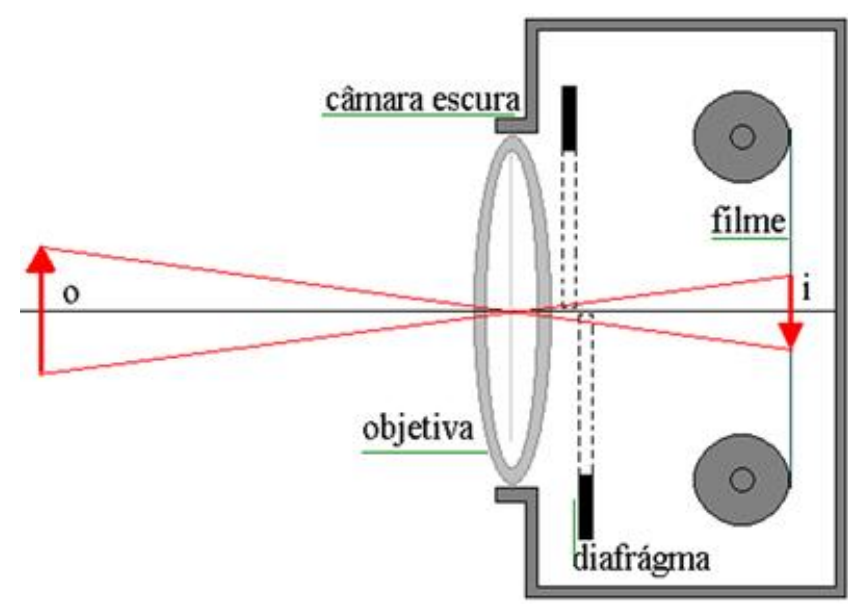

Figura 20 - Funcionamento da câmera fotográfica

Fonte: https://static.mundoeducacao.uol.com.br/mundoeducacao/conteudo/images/maquinafotografica.jpg

A lente que é colocada no lugar do orifício é denominada lente objetiva da máquina e possui um mecanismo que faz com que essa lente se aproxime ou se afaste do filme, a fim de que a imagem do objeto seja nítida nele, e esse processo (aproximação ou afastamento da lente) recebe o nome de focalização. 
Na máquina fotográfica é importante saber focalizar o objeto, a fim de se ter uma imagem nítida. Caso não se focalize corretamente o objeto observado, a imagem sairá totalmente sem foco. Essa focalização é feita da seguinte forma: se o objeto estiver afastado da lente, a focalização deve estar bem próxima do filme e vice-versa.

Embora o conceito e a funcionalidade de alguns componentes possam variar entre as diferentes marcas e categorias de câmeras, os elementos descritos abaixo (vide figura 21) estão presentes na maioria dos equipamentos:

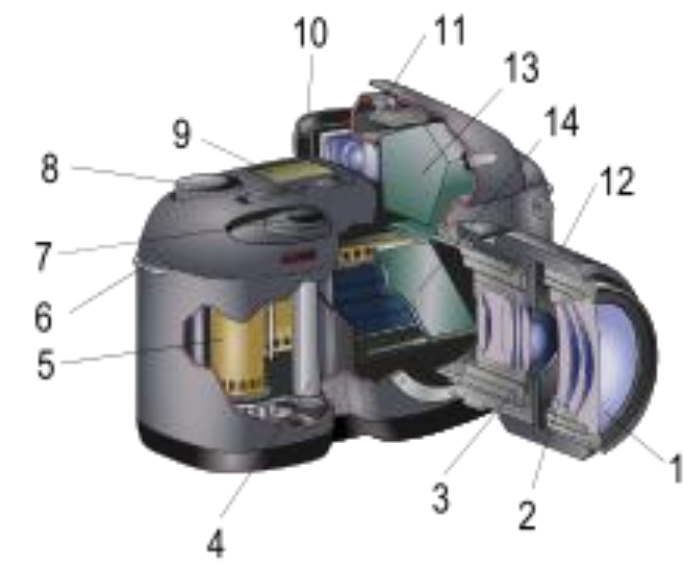

Figura 21 - Elementos de uma câmera fotográfica Fonte:

https://upload.wikimedia.org/wikipedia/commons/thumb/e/ef/Reflex_camera_\%28description\%29 .svg/220px-Reflex_camera_\%28description\%29.svg.png

1 - Elementos frontais: São parte da objetiva. Embora chamada de lente, tecnicamente refere-se a cada componente da objetiva.

2 - Elementos intermediários: Juntamente com os elementos frontais (lente) têm como objetivo principal focalizar a luz à altura do plano de foco, em que se encontra o filme ou sensor.

3 - Diafragma: Regula o diâmetro do orifício através do qual a luz penetra na câmera, e, portanto, é determinante em relação à quantidade de luz admitida.

4 - Obturador: Consiste em um dispositivo que abre e fecha de acordo com uma regulação de tempo, controlando o intervalo de tempo de exposição do filme à luz. 
5 - Mídia: O filme fotográfico ou sensor de imagem são substratos sobre o qual a luz é exposta. Como tal, são responsáveis por registrar a imagem recebida, armazenando-a em sua superfície (através de processos foto-químicos, no caso dos filmes) ou em outros componentes (por meio de processos eletrônicos, no caso de sensores).

6 - Cinta de fixação: Permite ao fotógrafo manter o equipamento preso ao seu corpo e acessa-lo com rapidez.

7 - Disparador ou gatilho: O botão que permite ao fotógrafo disparar a câmera e realizar uma fotografia.

8 - Comando do aparelho: Frequentemente câmeras possuem uma variedade de modos de exposição pré-configurados para situações específicas, como atividades esportivas, cenas ao ar livre, cenas noturnas e outras. $\mathrm{O}$ comando do aparelho permite ao usuário escolher uma dessas opções ou, no caso de câmeras mais avançadas, também temos modo de operação manual que permitem maior controle sobre as variáveis do processo fotográfico.

9 - Contador de quadros: Dispositivo que permite a uma câmera fotográfica indicar o número de fotografias já realizadas ou ainda não realizadas em um filme fotográfico que se encontra dentro da câmera.

10 - Visor: Em câmeras SLR consiste em um visor óptico alimentado pela luz refletida no pentaprisma. Em câmeras de telêmetro e de visor paralelo consiste em um visor óptico alimentado diretamente pela luz da cena. As câmeras mirrorless, possuem um visor eletrônico, e câmeras lambe-lambe e TLR não possuem um visor propriamente dito, pois utilizam o vidro de focagem como auxílio para composição da cena a ser fotografada. As câmeras digitais possuem um visor adicional do tipo display de cristal líquido (LCD), que permite ao operador visualizar facilmente as imagens que serão e que já foram fotografadas. 
11 - Sapata de flash: Permite acoplar um equipamento de flash à câmera e disparálo.

12 - Dispositivo de focagem: Um anel ao redor da objetiva, que permite mover os grupos de elementos desta e ajustar o foco da imagem projetada no filme ou sensor. As câmeras mais atuais contam com componentes que lhe permitem focar automaticamente.

13 - Pentaprisma ou vidro de focagem: Permite ao fotógrafo visualizar e compor a cena que será fotografa ou filmada.

14 - Espelho de reflexo: É responsável por desviar a luz em direção ao pentaprisma ou diretamente à tela de focagem, dependendo do tipo de câmera. Em câmeras SLR o espelho desloca-se uma vez que o gatilho é disparado, de forma a dar passagem à luz, e por esse motivo a imagem enviada ao visor é interrompida durante a realização de uma fotografia.

A abordagem histórica dos conteúdos matemáticos é um dos caminhos que o professor pode escolher para mediar a construção do conhecimento. Ela é fonte de seleção e constituição de métodos para elaboração de sequências adequadas aos diferentes tópicos de ensino da Matemática escolar. Ou seja, é muito importante para motivar e atrair a atenção dos alunos da Educação Básica.

Segundo BERLINGHOFF e GOUVÊA (2008), a presença da história nas aulas de matemática fornece uma visão ampla dessa ciência, contrariando a de uma coleção arbitrária de informações. "As pessoas agem por uma razão, e tipicamente constroem seu trabalho sobre outros anteriores em uma vasta rede de colaboração entre as gerações. A informação histórica nos permite compartilhar essa "grande figura"' (p. 3).

No próximo capítulo abordarei alguns conteúdos matemáticos presentes na fotografia. 


\section{A Matemática na fotografia}

\section{1.}

\section{As frações e a velocidade do obturador}

Podemos afirmar que no momento de capturar uma imagem a Matemática está presente, uma vez que a fotografia envolve noção de fração para explicar a velocidade do obturador, envolve também área do círculo para ter noção do funcionamento do diafragma da lente, além de envolver sequência de Fibonacci para que consiga obter uma composição harmoniosa, entre outros conceitos matemáti$\cos$.

Fotografia significa escrever com a luz e uma das maneiras de controlar a quantidade de luz numa fotografia, ou seja, a quantidade de luz que vai entrar na câmera fotográfica no momento da foto é com o obturador, que é o nome dado a uma pequena "janela" dentro da câmera, que abre no momento do disparo para capturar a luz que passa pela lente. O tempo que o obturador fica aberto é chamado de tempo de exposição ou velocidade de obturação, ou seja, o tempo de exposição do filme para câmeras analógicas ou do sensor para câmeras digitais. A variação deste tempo determina a quantidade de luz que será capturada para a fotografia. A medida da velocidade do obturador é dada em frações de segundos: 1, $1 / 2,1 / 4,1 / 250$, etc, porém, são geralmente tratadas, por exemplo, como velocidade 60 (referente a 1/60) ou velocidade 100 (referente a 1/100) e, assim, sucessivamente.

O obturador é como uma cortina que protege o sensor da câmera, abrindo somente para captar a luz no momento em que o disparador é acionado. Ele fica atrás do diafragma, no corpo da câmera. Cabe ressaltar que, a velocidade do obturador é uma das variantes mais utilizadas para alterar o resultado final da foto.

Nas câmeras digitais SLR são encontrados dois obturadores, o obturador mecânico, que determina o tempo de exposição de acordo com a configuração do fotógrafo e o obturador eletrônico, que serve para acionar o sensor digital da câmera. Além destes, temos, também, o raro obturador central, encontrado em câmeras fotográficas médias. Ele é composto por lamelas giratórias, que abrem e fecham de acordo com a configuração determinada pelo fotógrafo. Ele é bem mais 
preciso que os outros, permitindo ao fotógrafo sincronizá-lo com o flash de alta velocidade.

Para objetos em movimento, há outro fator que influencia no resultado da imagem. Quanto maior for a velocidade do obturador, maior será a capacidade de congelar um objeto, mesmo que ele esteja se movimentando, e quanto menor for a velocidade do obturador, maior será a chance do objeto ficar tremido ou com rastros na fotografia. Isso acontece porque durante o tempo em que o obturador fica aberto, a câmera capta tudo que está a sua frente, se for um objeto em movimento a câmera irá captar o movimento, o que dará um efeito de rastro na imagem.

A seguir temos duas fotografias na mesma cachoeira (vide figura 22), porém com configurações diferentes. Na primeira imagem, temos a velocidade do obturador $1 / 800$, ou seja, imagem capturada com alta velocidade e, por isso, conseguimos ver a água da cachoeira com detalhes. Enquanto na segunda imagem, temos velocidade do obturador $1 / 2$, ou seja, com baixa velocidade, logo temos um efeito de movimento.
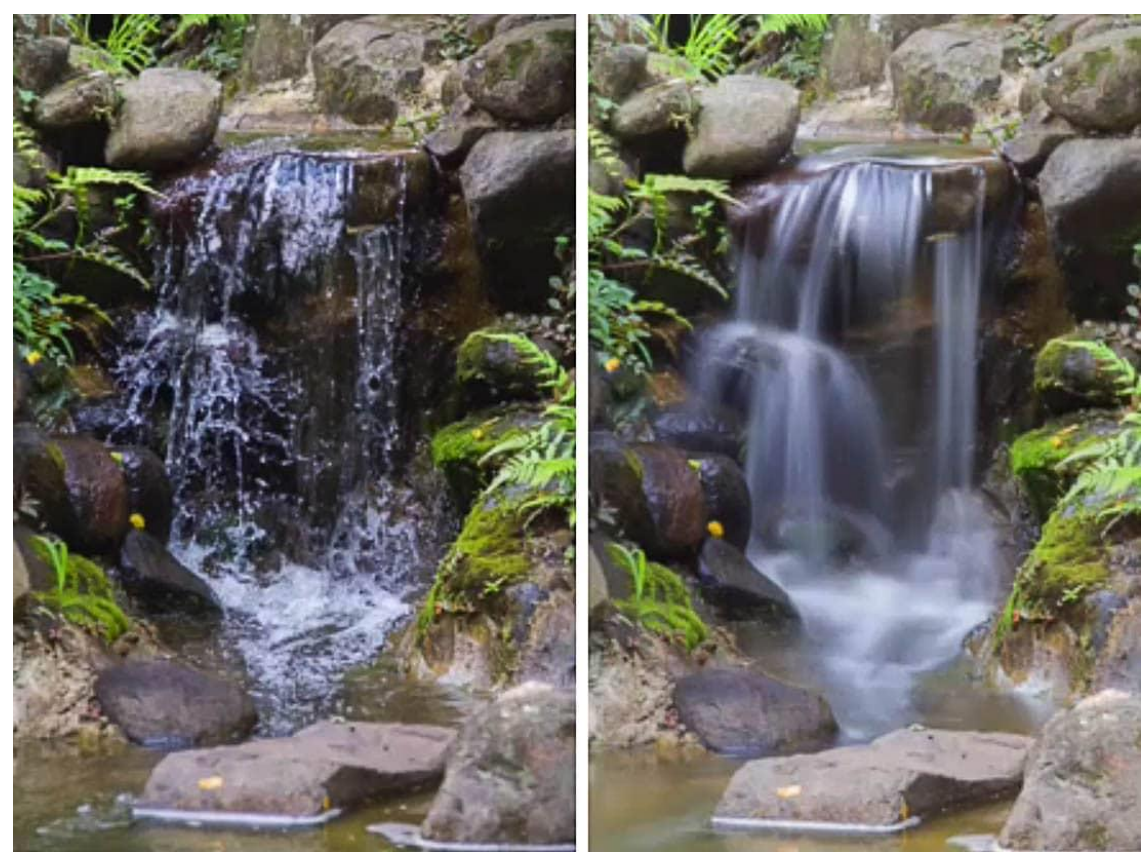

Figura 22 - Fotografias com velocidade de obturador diferente Fonte: https://caradafoto.com.br/wp-content/uploads/2016/04/efeitoveu-CaraDaFoto.jpg

A velocidade do obturador, também chamada de tempo de exposição é exatamente o tempo que o obturador da câmera leva para abrir e fechar. Ajustando a velocidade da câmera para 4 ou 5 segundos, é possível verificar que 
todos os movimentos que passarem na frente da câmera durante este tempo serão captados. Se fotografarmos uma corrida (vide figura 23) com velocidade muito baixa, 1/8000, por exemplo, será possível verificar que o atleta ficará completamente congelado no ar, conforme mostra a fotografia abaixo.

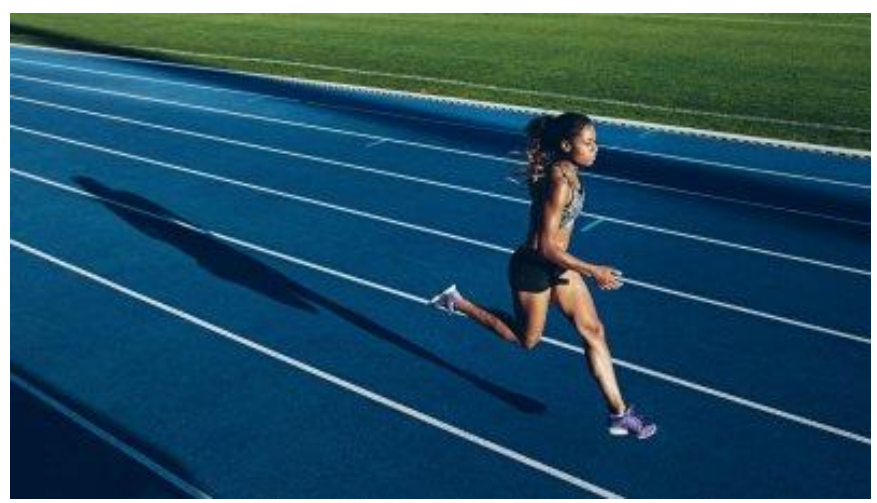

Figura 23 - Atleta correndo Fonte:

https://cdn.mensagenscomamor.com/content/images/p000025301.jpg?v=1\&w=400\&h=225\&c=1

A representação numérica da velocidade do obturador é uma fração: 1/x, onde o 1 , numerador da fração, representa 1 segundo e o x, denominador da fração, representa a fração de segundo. Vejamos alguns valores de velocidade presentes nas câmeras: $1 / 8000 \mathrm{~s}, 1 / 4000 \mathrm{~s}, 1 / 2000 \mathrm{~s}, 1 / 1000 \mathrm{~s}, 1 / 500 \mathrm{~s}, 1 / 250 \mathrm{~s}, 1 / 125$ s, $1 / 60 \mathrm{~s}, 1 / 30 \mathrm{~s}, 1 / 15 \mathrm{~s}, 1 / 8 \mathrm{~s}, 1 / 4 \mathrm{~s}, 1 / 2 \mathrm{~s}, 1 \mathrm{~s}$ e B (de bulb) - o obturador ficará aberto enquanto o botão de disparo permanecer pressionado.

Fotografando um mesmo cata-vento (vide figura 24) em três momentos distintos, podemos observar a diferença entre as três fotos, que apresentam valores diferentes para a velocidade do obturador: 1/500 na primeira imagem, 1/30 na segunda imagem e 1/4 na terceira imagem.

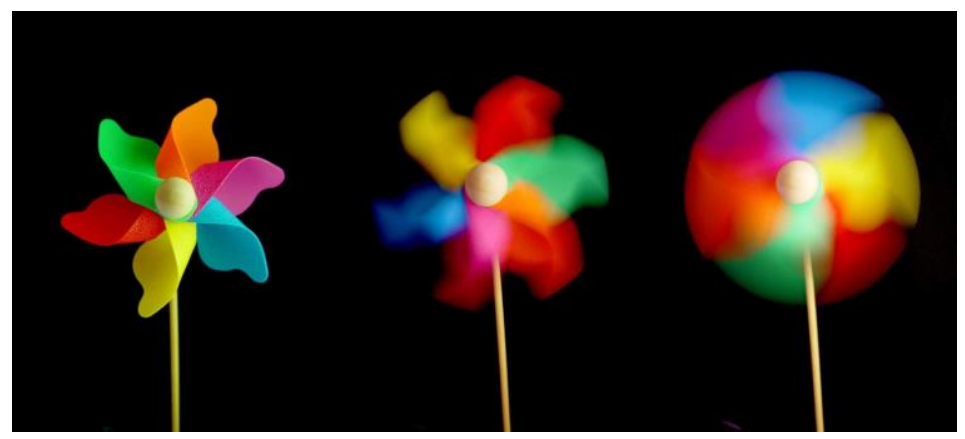

Figura 24 - Diferentes valores da velocidade do obturador para fotografias de um cata-vento Fonte: https://blog.emania.com.br/wp-content/uploads/2016/02/Windflower-05237-nevit.jpg 


\section{2.}

\section{A área do círculo e o diâmetro (abertura) da lente}

A luminosidade de uma lente depende do seu diâmetro e da sua distância focal. Como estas duas grandezas variam inversamente uma em relação à outra, ou seja, quanto maior o diâmetro da lente, mais luminosa ela é, e quanto maior a distância focal, menor a luminosidade, é possível medir a característica de luminosidade de uma lente em relação à outra através do quociente "distância focal / diâmetro da lente".

Uma lente comum (exceto a lente com zoom) não pode ter sua característica de distância focal alterada, porém pode ter sua característica de diâmetro alterada, através de um dispositivo denominado diafragma.

O diafragma é o dispositivo que regula a abertura do sistema óptico, composto por um conjunto de finas lâminas justapostas, que se localizam dentro da lente e permitem regular a intensidade de luz que passa pela lente para chegar ao sensor. Quando o diafragma está mais aberto, a quantidade de luz é maior, logo quando o diafragma está mais fechado, a quantidade de luz é menor. Além disso, o diafragma tem uma função estética, pois quando está muito fechado não é possível observar o efeito de fundo desfocado.

O diafragma está ligado diretamente a Matemática, pois cada ponto do mesmo, que pode ser chamado de $f$ ou $f$-stop, apresenta valores de uma progressão geométrica de razão 2 . Os pontos $f$ ou $f$-stop são 1, 1.4, 2, 2.8, 4, 5.6, 8, 11, 16, 22, 32, 45 e 64. Esses números seguem uma progressão geométrica intercalada (vide figura 25).

$$
\begin{array}{rlrl}
1,1.4,2,2.8,4,5.6,8,11,16,22,32,45 & \mathrm{e} 64 \\
1 \times 2 & =2 & 1,4 \times 2 & =2,8 \\
2 \times 2 & =4 & 2,8 \times 2 & =5,6 \\
4 \times 2 & =8 & 5,6 \times 2 & =11(11,2) \\
8 \times 2 & =16 & 11 \times 2=22 \\
16 \times 2 & =32 & 22 \times 2 & =44 \\
32 \times 2 & =64 &
\end{array}
$$

Figura 25 - Ponto (f-stop) do obturador Fonte: Imagem criada pelo autor 
Quanto maior o número $f$ ou $f$-stop atribuído, menor será a abertura, e, consequentemente, menor será a passagem de luz pelo diafragma. Ao contrário, quanto menor o número $f$ ou $f$-stop atribuído, maior será a abertura, e logo, maior será a passagem de luz pelo diafragma.

Como a área pela qual passa a luz no diafragma é a de um circulo, existe uma fórmula matemática que a relaciona com seu diâmetro: a área de um círculo dobra se seu diâmetro for multiplicado por $\sqrt{2}$ e fica dividida pela metade se o mesmo diâmetro for dividido, também, por $\sqrt{2}$.

A relação entre a área e o diâmetro de um círculo é demonstrada da seguinte maneira:

A área de um círculo é $A=\pi \cdot r^{2}$. Sendo $A_{1}=$ área menor e $A_{2}=$ dobro da área $A_{1}$, tem-se que $A_{2}=2 . A_{1}$, ou seja, $\pi\left(r_{2}\right)^{2}=2 . \pi\left(r_{1}\right)^{2}$, o que é equivalente a $\left(r_{2}\right)^{2}$

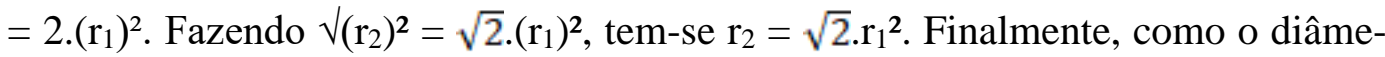
tro é o dobro do raio, $2 \cdot \mathrm{r}_{2}=2 \cdot \mathrm{r}_{1} \cdot \sqrt{2}$, ou seja, $\mathrm{d}_{2}=\mathrm{d}_{1} \cdot \sqrt{2}$

A atual escala de abertura utilizada é obtida através da fração: $f=\frac{D F}{A}$, onde:

- $f$ é o valor do diafragma obtido;

- DF é a distância focal, em milímetros;

- A é o diâmetro, em milímetros, da abertura efetiva do diafragma, ou pupila de entrada.

Seguindo o raciocínio de frações, temos que 1/2 (meio) é maior do que 1/4 (um quarto), que por sua vez é maior do que 1/8 (um oitavo), e assim por diante. Sendo assim, ao fracionar a luz, temos que o maior valor pode ser 1 (um inteiro) e o menor será 1/64 (um sessenta e quatro avos).

Começando em $f / 1$ e indo até $f / 64$, a cada número $f$ seguinte na escala, a quantidade de luz que passa pelo diafragma é reduzida pela metade. Com $f / 1.4$, teremos duas vezes menos luz passando pelo diafragma do que com $f / 1$. Com $f / 2$, duas vezes menos do que com $f / 1$.4 Com $f / 2.8$, duas vezes menos do que com $f / 2$, e, assim, sucessivamente.

O inverso também funciona da mesma maneira, só que ao invés de dividir pela metade a quantidade de luz, ele duplica. Por exemplo, com $f / 45$, teremos duas 
vezes mais luz passando pelo diafragma do que com $f / 64$. Com $f / 32$, duas vezes mais do que com $f / 45$. Com $f / 22$, duas vezes mais do que com $f / 32$, e assim por diante. A imagem abaixo explica visualmente essas informações, pois temos um diafragma com suas aberturas e números $f$ correspondentes aproximados.

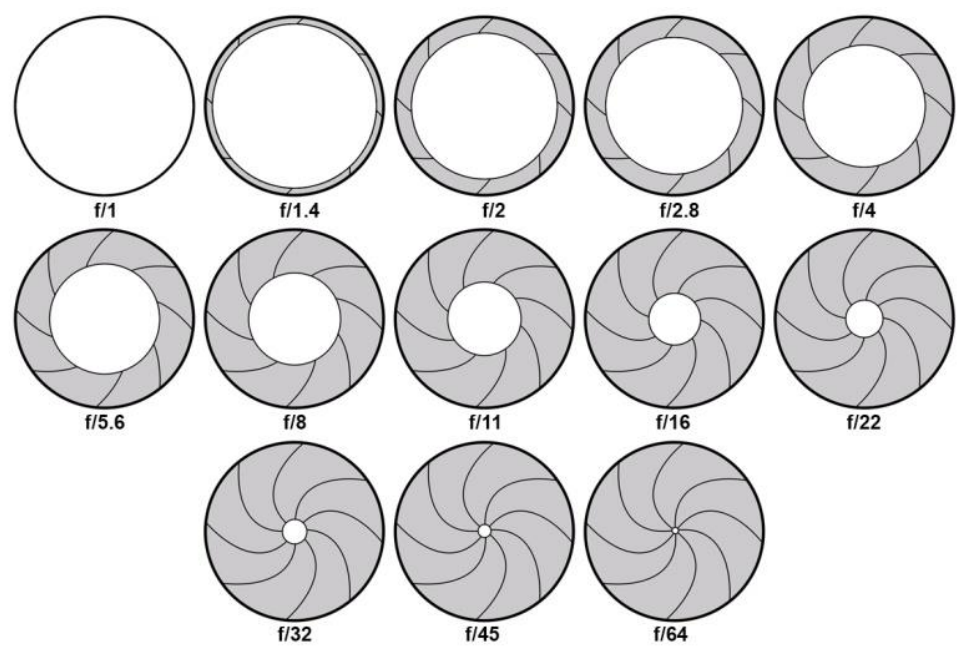

Figura 26 - Abertura do diafragma Fonte: https://2.bp.blogspot.com/1EaSONscI2E/WBJ5CO584aI/AAAAAAAAADo/ZA95IZhavp0v5x3fhMTQeXO22wtRt24wCLcB/s640/Abertura-do-Diafragma.jpg

Numa outra imagem temos as diferentes quantidades de passagem de luz (vide figura 27), dependendo do número $f$ ou $f$-stop atribuído na exposição. Podemos observar que mesmo pequenos valores intermediários podem fazer grandes diferenças na quantidade de luz. Todos os outros controles de exposição se mantiveram exatamente os mesmos em cada exemplo, a única coisa alterada foi a abertura do diafragma.

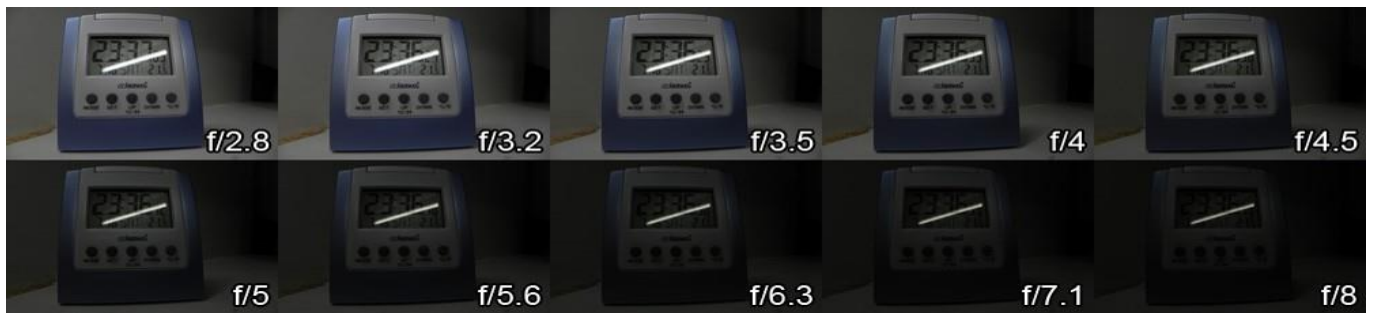

Figura 27 - Diferentes quantidades de passagem de luz Fonte:

https://static.wixstatic.com/media/c12431_065d7b954d004bf092261be0107de992 mv2.jpg/v1/fill /W_740,h_196,al_c,q_90,usm_0.66_1.00_0.01/c12431_065d7b954d004bf092261be0107de992 m v2.webp 


\section{3.}

\section{A sequência de Fibonacci e a proporção áurea}

Toda fotografia começa com uma composição e o modo como se enquadra uma cena é a construção básica para tirar uma boa fotografia. A proporção áurea pode ajudar a melhorar a qualidade da composição das fotografias. Além dela, temos, também, a regra dos terços, que é a regra de composição mais conhecida.

A base da proporção áurea está em Matemática, pois na verdade trata-se de um número encontrado através de uma linha (ou às vezes outra forma) e dividindo-a em duas partes. Quando uma linha (ou forma) é dividida em duas partes com base na proporção áurea, ela será dividida de tal forma que, se dividirmos o comprimento da seção mais longa pelo comprimento da menor seção, ela será igual ao original comprimento da forma dividida pela seção mais longa.

Ao fazermos as contas, encontramos uma proporção de 1 a 1.618, e se continuarmos a dividir essa forma com base nesse princípio, acabará com uma forma igual a da figura abaixo (vide figura 28).

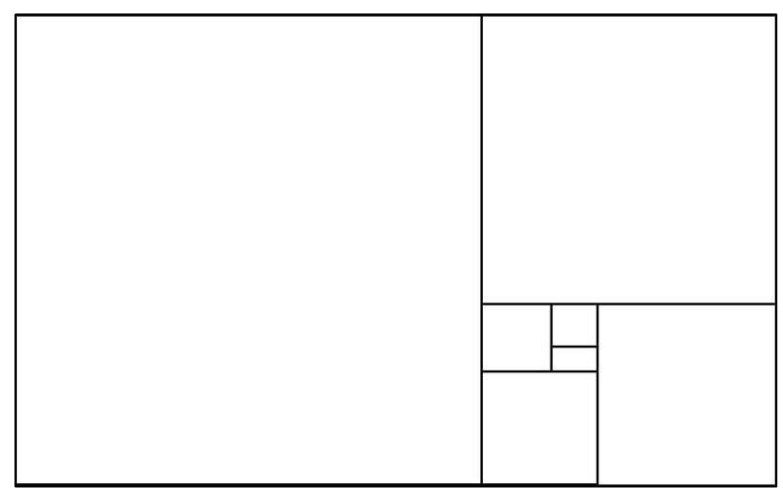

Figura 28 - Divisão seguindo a proporção áurea Fonte: https://static-cse.canva.com/blob/181359/113.c6aa8dc6.jpg

É possível chegar a mesma forma usando a sequência de Fibonacci, que é um conjunto de números encontrado somando os dois números anteriores, onde cada número, a partir do terceiro, é a soma dos 2 imediatamente anteriores: 0, 1, 1, $2,3,5,8,13,32,34 \ldots(0+1=1,1+1=2,1+2=3 \ldots)$. Se forem criados quadrados, cujos tamanhos dos lados são os números da sequência de Fibonacci, temse a espiral (vide figura 29). 


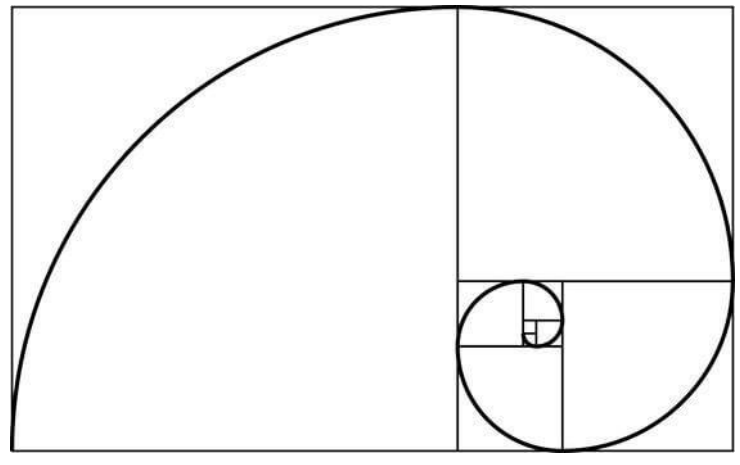

Figura 29 - Proporção áurea

Fonte: https://imagens-revista-

pro.vivadecora.com.br/uploads/2019/03/Propor\%C3\%A7\%C3\%A3o-\%C3\%A1urea.jpg

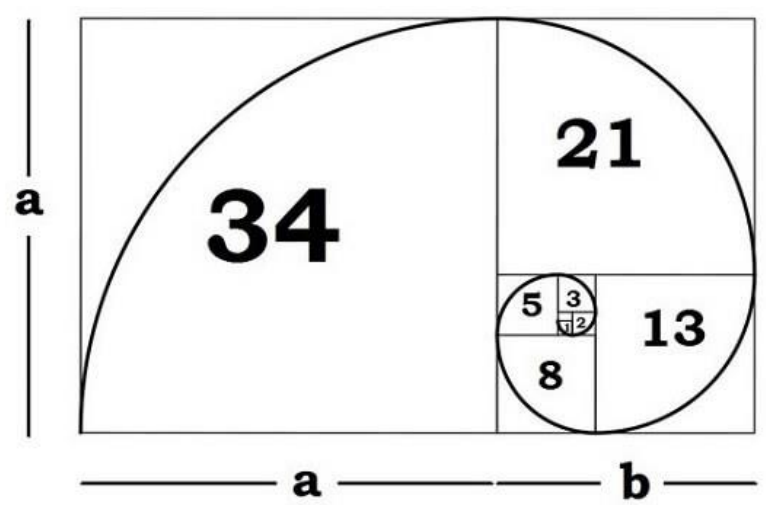

Figura 30 - Proporção áurea e a sequência de Fibonacci Fonte: https://imagens-revista-

pro.vivadecora.com.br/uploads/2019/03/propor\%C3\%A7\%C3\%A3o-\%C3\%A1ureasequ $\%$ C $3 \%$ AAncia-de-Fibonacci.jpg

A sequência de Fibonacci está ligada diretamente à proporção áurea (vide figura 30). A sequência de números infinita descrita por Leonardo Fibonacci no século XIII, se disposta em quadrados distribuídos geometricamente em um triângulo, forma o que ficou conhecido como "retângulo de ouro". A proporção áurea se encaixa perfeitamente no retângulo de ouro (vide figura 30). A proporção áurea é considerada uma espiral perfeita, tão agradável aos olhos que passou a ser utilizada na arte, no design e na arquitetura. A proporção áurea também pode ser encontrada na natureza, desde moléculas de $\mathrm{ADN}$ até pétalas de flores, de furacões à Via Láctea e até no corpo humano.

O fato relevante é que a espiral de Fibonacci é agradável ao olho humano, pois é perfeitamente equilibrada, ou seja, por isso é tão usada nas fotografias para que possa atingir uma composição harmoniosa. Além disso, a proporção áurea 
passa da Matemática para a Arte. A Monalisa (vide figura 31) e a Última Ceia, por exemplo, são duas pinturas que usam a proporção áurea. Na fotografia, a proporção áurea pode ser usada para identificar o assunto principal e, ao mesmo tempo, liderar o olhar do espectador por toda a imagem.

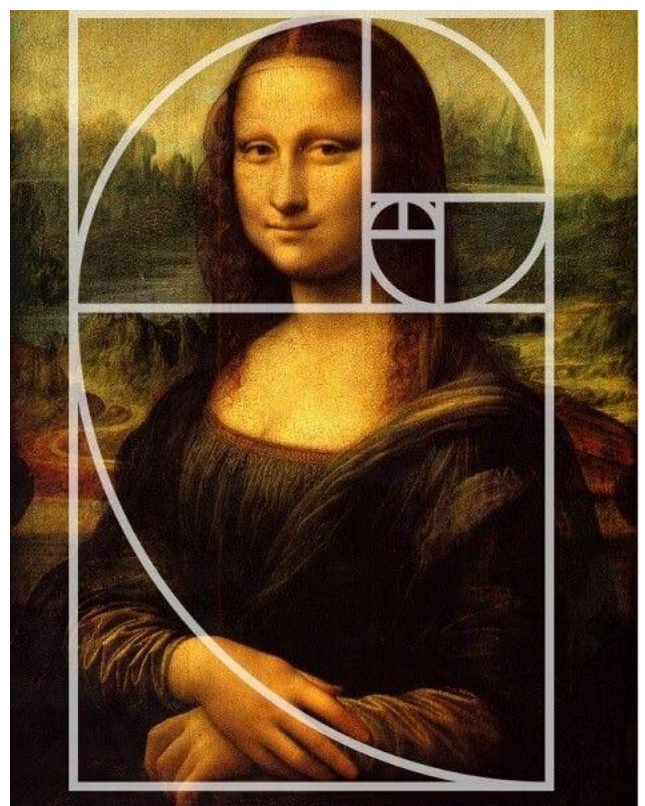

Figura 31 - Proporção áurea: Monalisa Fonte: https://i.pinimg.com/564x/68/28/25/6828257ba0e2d9b2ee1d032e62c7b361.jpg

Existe outra maneira de usar a proporção áurea para compor uma fotografia. Em vez de usar a espiral, cria-se uma grade como na regra dos terços (vide figura 32), mas que use uma proporção de 1:1,618, em vez de dividir a estrutura em partes iguais.

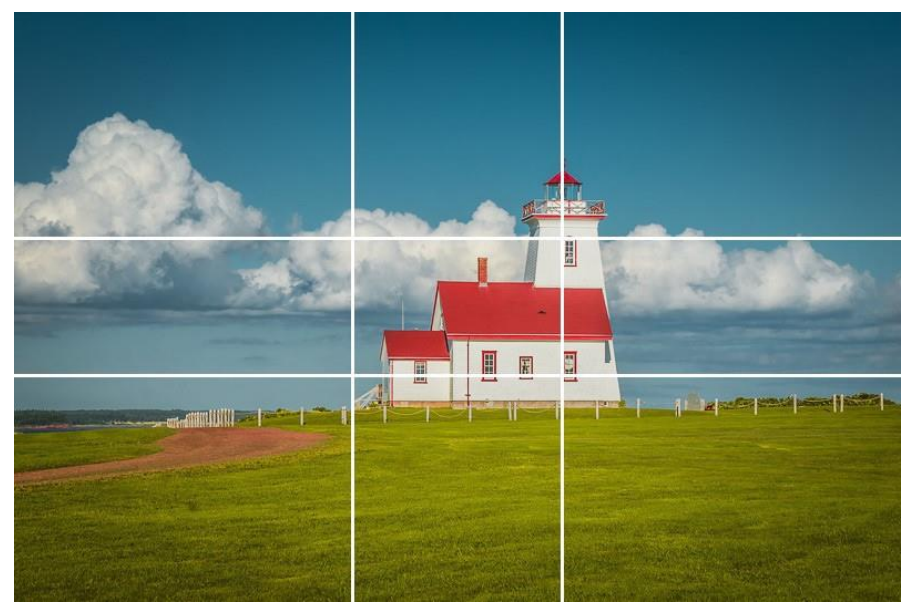

Figura 32 - Fotografia usando grade Fonte: https://miro.medium.com/max/700/1*-o5N_nc3f1M9P-ti8kA4iQ.jpeg 
Essa grade, chamada Phi Grid, é semelhante à regra dos terços, mas como é baseada na proporção áurea, as distâncias são um pouco diferentes. As seções centrais são menores que as seções externas.

Tanto a espiral quanto a grade são boas formas para se manter em mente quando compomos uma imagem. Uma pode funcionar melhor para um tipo de imagem, enquanto a outra para outro tipo. Por exemplo, a grade tende a funcionar bem para compor paisagens, enquanto a espiral é frequentemente usada para retratos, colocando o olho do dito sujeito na menor parte da espiral.

É um princípio de composição de ordenar os elementos num trabalho de tal forma que o resultado final seja esteticamente agradável para o espectador. A origem dessa regra é Matemática, pois duas grandezas, $a$ e $b$, estão em proporção áurea se a proporção delas for a mesma que a razão de sua soma $(a+b)$ para a maior das quantidades.

Alinhados desta maneira, $a$ e $b$ parecem agradáveis aos olhos porque estão em proporção áurea (vide figura 33). O valor de $a$ é aproximadamente 1.618 vezes maior que $b$. A proporção áurea ajuda-nos a criar composições que parecem naturais, orgânicas e agradáveis aos olhos.

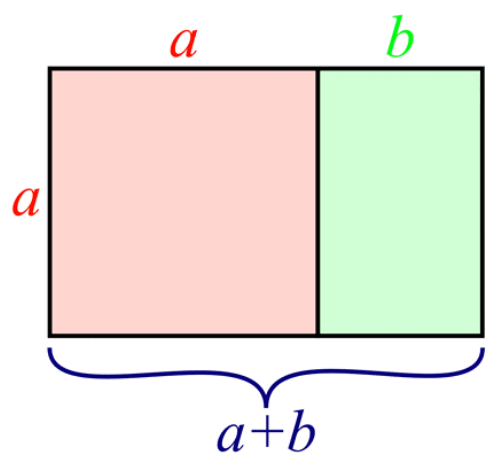

Figura 33 - Proporção áurea entre a e b

Fonte: https://miro.medium.com/max/450/1*CUiRZZ_5R0u4ztMkinoAow.png

Quando olhamos para uma fotografia baseada na proporção áurea, ela atrai naturalmente nosso interesse para o ponto principal. Os nossos olhos tendem a seguir as linhas principais ou a olhar para uma imagem de maneira diferente. Ao utilizar estas fórmulas, iremos perceber que o assunto (parte principal) muitas vezes acabará por ser colocado um pouco fora do centro - para a esquerda ou para a direita, e, muitas vezes, para cima e para baixo no quadro. Isso não quer 
dizer que uma imagem centralizada não seja visualmente agradável, mas seguir esses guias pode ajudar a criar uma imagem mais interessante.

Sabe-se que a proporção áurea foi usada por escultores e arquitetos desde a Grécia Antiga até pintores renascentistas, como Sandro Boticelli (1445-1510) e Leonardo da Vinci (1452-1519). Com essa fórmula chega-se a um número irracional instigante, ligado à natureza do crescimento: na organização pentagonal dos átomos de cristais de quartzo, na espiral de um girassol (vide figura 34), em algumas proporções do corpo humano, no caracol (vide figura 35) e foi encontrado até mesmo no ciclo temporal das ondas cerebrais. Até mesmo a grande pirâmide de Queops segue exatamente a proporção áurea, fato confirmado por extensas medições.

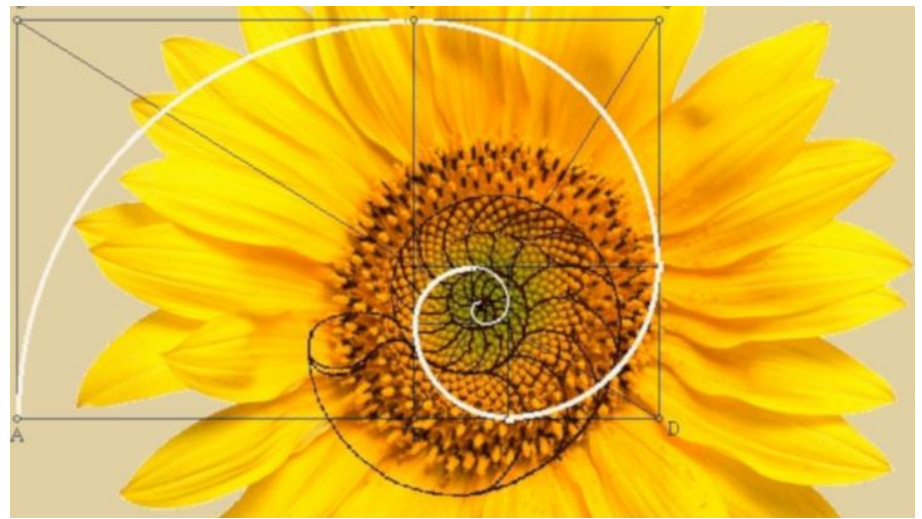

Figura 34 - Proporção áurea: Girassol

Fonte: https://2.bp.blogspot.com/-

A4ADFUC7gkg/W5kCC28p_yI/AAAAAAAAGUE/RJmkGkhejwMVbNl2RDzFJFTgXkXJa2BQCLcBGAs/s1600/golden-ratio-flower.png

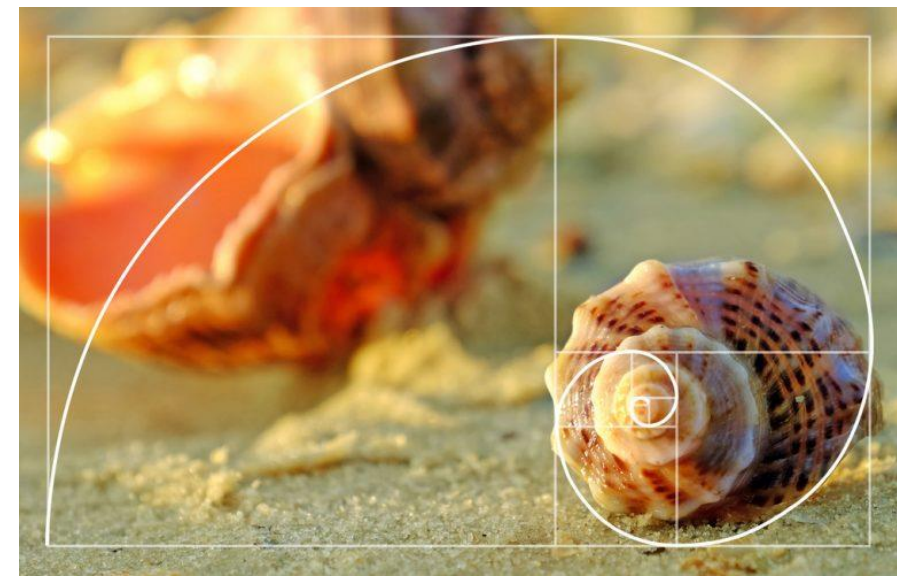

Figura 35 - Proporção áurea: Caracol

Fonte: https://blog.fotoregistro.com.br/wp-content/uploads/2017/08/shutterstock 430253152768x495.jpg 
A fórmula da proporção áurea, que é a razão entre " $a+b$ " e " $a$ " é igual à razão entre " $a$ " e " $b$ ":

$$
\frac{a+b}{a}=\frac{a}{b}=\varphi
$$

É por isso chamado de número divino. Seu valor arredondado é de 1,618 e é representado pela letra grega $\varphi$ (phi) em homenagem a Phidias, um grande escultor grego do século V A.C. ao qual estudiosos atribuem o emprego da proporção áurea em suas obras, notadamente nas estátuas do Partenon (vide figura 36). O número de ouro representa, assim, uma constante de harmonia e beleza.

A famosa "regra do terço" é uma simplificação da proporção áurea. Muitos confundem achando que é a mesma coisa, mas não é. A proporção áurea é 1.618 e a proporção do terço é 1.666 .

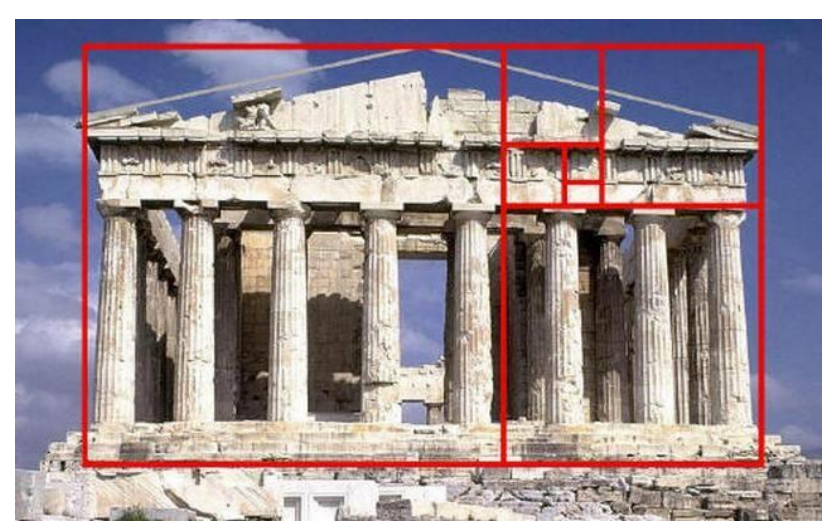

Figura 36 - Proporção áurea: Partenon

Fonte: https://imagens-revista-

pro.vivadecora.com.br/uploads/2019/03/Propor\%C3\%A7\%C3\%A3o-\%C3\%A1urea-no-Templode-Parthenon.jpg

Johannes Kepler, astrônomo das três leis planetárias, notou, em 1611, que a divisão entre um número de Fibonacci e seu antecessor leva ao número de ouro quando se avança para valores cada vez maiores na sequência. Matematicamente, isto quer dizer que $F(n) / F(n-1)$ tende para o número de ouro quando $n$ tende para infinito.

$$
\lim _{n \rightarrow \infty} \frac{F_{n}}{F_{n-1}}=\varphi
$$


A tabela a seguir ilustra o fato descrito acima, pois cada número da coluna " $F_{n}$ " representa um número de Fibonacci. Na última coluna, temos o resultado da divisão de um número de Fibonacci por seu antecessor.

\begin{tabular}{|c|c|c|}
\hline$n$ & $F_{n}$ & $F_{n} / F_{n-1}$ \\
\hline 1 & 1 & \\
\hline 2 & 1 & $1 / 1=1$ \\
\hline 3 & 2 & $2 / 1=2$ \\
\hline 4 & 3 & $3 / 2=1,5$ \\
\hline 5 & 5 & $5 / 3=1,66667$ \\
\hline 6 & 8 & $8 / 5=1,6$ \\
\hline 7 & 13 & $13 / 8=1,625$ \\
\hline 8 & 21 & $21 / 13=1,61538$ \\
\hline 9 & 34 & $34 / 21=1,61905$ \\
\hline 10 & 55 & $55 / 34=1,61765$ \\
\hline 11 & 89 & $89 / 55=1,61818$ \\
\hline 12 & 144 & $144 / 89=1,61798$ \\
\hline 13 & 233 & $233 / 144=1,61806$ \\
\hline
\end{tabular}

Tabela 1 - Divisão de um número de Fibonacci por seu antecessor

\section{4.}

\section{Conversão da sequência de Fibonacci para razão áurea}

Consideremos a sequência de Fibonacci que é definida indutivamente por $F_{1}=1$, $F_{2}=2$,

$$
F_{\mathrm{n}+2}=F_{\mathrm{n}}+F_{\mathrm{n}+1}
$$

Estamos interessados na razão

$$
Q_{n}=\frac{F_{n+1}}{F_{n}}
$$

Nós vamos demonstrar a seguir que

$$
\lim _{n \rightarrow \infty} Q_{n}=\phi,
$$

onde 


$$
\varphi=\frac{1}{2}(1+\sqrt{5})
$$

é o número de ouro.

Dividindo por $F_{\mathrm{n}+1}$ na fórmula $(0.1)$ obtemos

$$
Q_{n+1}=\frac{1}{Q_{n}}+1
$$

As raízes da equação do segundo grau

$$
x^{2}-x-1=0
$$

são $\varphi=1 / 2(1+\sqrt{ } 5)$ e $\varphi=1 / 2(1-\sqrt{5})$. Resolvendo então a inequação do segundo grau

$$
x^{2}-x-1>0
$$

obtemos $\mathrm{x}>\varphi$ ou $\mathrm{x}<\varphi$. Como a sequência de razões $Q_{n}$ é sempre positiva, concluímos que $Q_{n+1}<Q_{n}$ se e somente se $Q_{n}>\varphi$.

Sabemos que $Q_{1}=2>\varphi$. Vamos verificar por indução que $Q_{n}>\varphi$ para todo n. Pela hipótese de indução assumimos que $Q_{n}>\varphi$ e vamos mostrar que $Q_{n+1}>\varphi$. Temos que

$$
Q_{n+1}=\frac{1}{Q_{n}}+1<\frac{1}{\varphi}+1=\varphi
$$

demonstramos o que queríamos.

Concluímos que a sequência $Q_{n}$ é decrescente e sempre maior do que $\varphi$. Uma sequência decrescente e limitada inferiormente de números reais tem sempre um limite. Denotamos por $L$ tal limite. Da equação (0.2) obtemos que

$$
L=\frac{1}{L}+1
$$

de onde concluímos que $L=\varphi$.

\section{5.}

\section{A regra do terço}

É uma técnica utilizada na fotografia para se obter melhores resultados. Para utilizá-la deve-se dividir a fotografia em 9 quadrados, traçando duas linhas horizontais e duas verticais imaginárias, e posicionando nos quatro pontos de cru- 
zamento o objeto que se deseja destacar para se obter uma foto equilibrada e mais harmoniosa (vide figura 37). Em alguns casos, manter o objeto principal da foto em algum desses pontos chamará mais a atenção, ou seja, o objeto centralizado não significa uma foto mais equilibrada. Os dois terços da imagem atingem o número 0,666 .

As câmeras fotográficas e celulares de hoje em dia já vêm com essas linhas no visor para ajudar na hora do clique. Além disso, temos alguns aplicativos como o Lightroom ou o Photoshop, que, também, possuem essas linhas prédefinidas.

Para obter uma boa fotografia de horizontes o interessante é manter um terço da imagem com um objeto, e dois terços com outro. Quando o céu for impactante, chamativo, recomenda-se priorizar o mesmo.

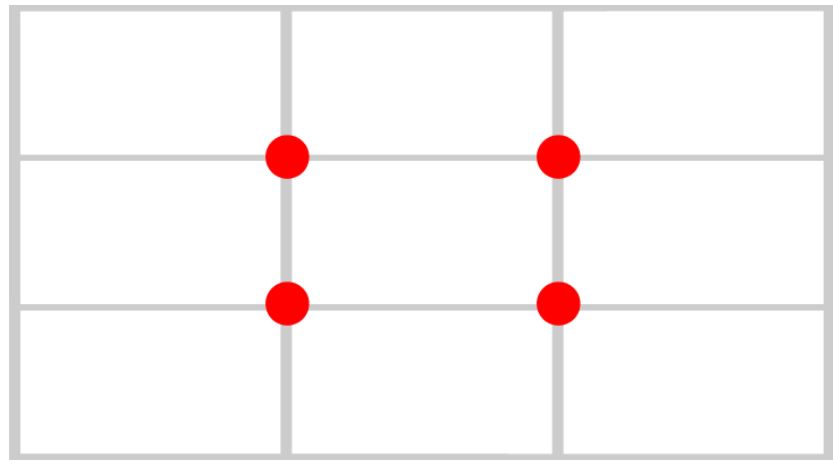

Figura 37 - Linhas imaginárias para regra dos terços Fonte: https://2.bp.blogspot.com/-

VN0mem0T17M/VGOJm5WIUnI/AAAAAAAAApY/AhsaPKM9C4Q/s400/regra-dos-tercos.gif

Não é necessária muita explicação para entender essa regra: basta pegar a imagem e desenhar mentalmente um "jogo da velha" nela. Os pontos importantes da sua foto devem ficar em alguma das 4 convergências dessas linhas recémdesenhadas. Se existirem linhas na imagem, dê preferência em posicioná-las junto às linhas do jogo da velha. Abaixo, nos pontos vermelhos, você vê onde enquadrar os itens preferenciais da foto:

O segredo é que cada foto tem suas características próprias e nem sempre é fácil definir o que vai aparecer nas bolinhas. O importante é que antes de tirar a foto o fotógrafo defina o que deve estar em evidência, e faça a composição de acordo com este item. 
Na foto abaixo (figura 38), o barco é o ponto de destaque e, por isso, ele se encontra na convergência inferior esquerda: o restante da cena só complementa e dá contexto.

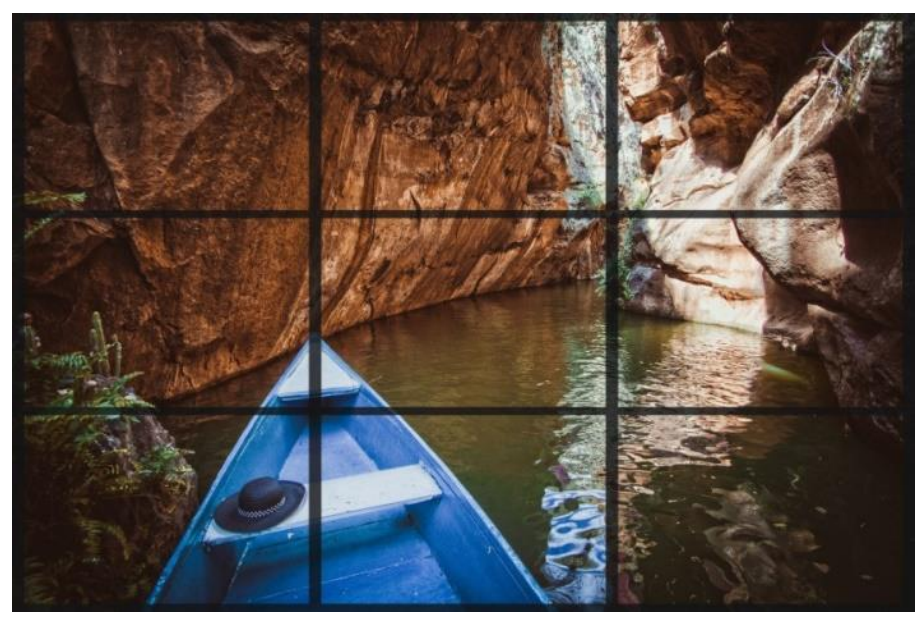

Figura 38 - Fotografia utilizando a regra dos terços

Fonte: http://www.dicasdefotografia.com.br/article-images/xingo-por-claudia-regina-850x562.jpg

Às vezes, em uma foto de paisagem, o fotógrafo vai se concentrar nas próprias linhas do terço - ao invés das bolinhas. O indicado é não centralizar o horizonte e os objetos. Se o céu está mais interessante, deixe-o em evidência deixando o horizonte abaixo da linha inferior, como na foto abaixo (vide figura 39).

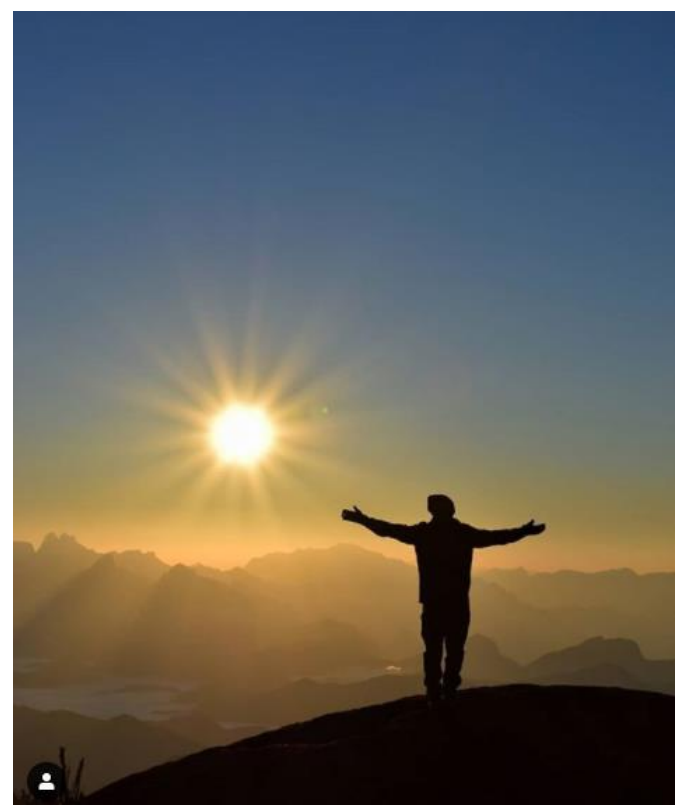

Figura 39 - Fotografia utilizando a regra dos terços Fonte: fotografia pessoal do autor 


\section{6.}

\section{Distância focal e ângulo de visão das objetivas}

A distância focal é, junto com a abertura do diafragma, uma das mais importantes características de uma objetiva. É a partir dela que o fotógrafo define, por exemplo, qual o campo de visão em que deseja trabalhar, ou ainda a maior ou menor aproximação de uma imagem.

A distância focal de uma objetiva é determinada a partir dos pontos nodais até os focais (vide figura 40), ou seja, é a distância, em milímetros, entre o ponto de convergência da luz até o ponto - sensor ou filme em máquinas fotográficas e filmadoras - onde a imagem focalizada será projetada. Quanto maior for a distância focal, menor será o ângulo de visão da imagem e maior será a aproximação dos objetos focalizados, devido ao corte realizado.

Todas as objetivas recebem classificações como grande angular, normal e teleobjetiva, e quase todas elas podem ser do tipo macro (que permite uma focalização de objetos mais próximos) ou não. Para cada tipo de lente, temos uma distância focal (vide figura 41).

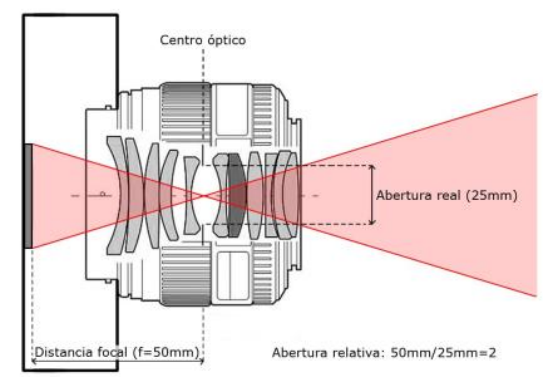

Figura 40 - Distância focal

Fonte: https://blog.emania.com.br/wp-content/uploads/2015/09/DistanciaFocal4.jpg

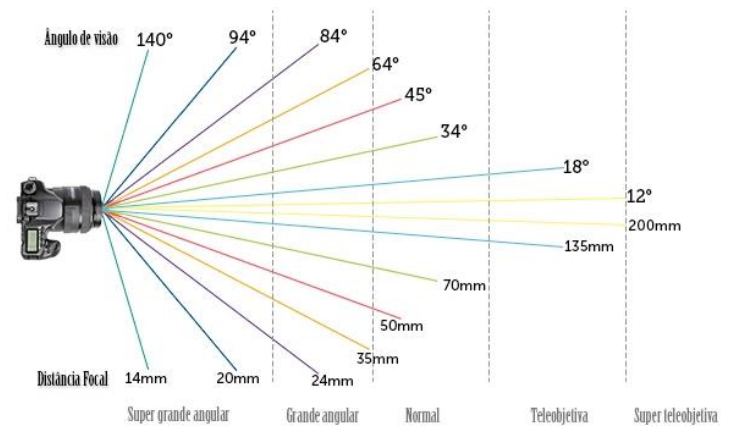

Figura 41 - Lentes e distâncias focais

Fonte: https://fotodicasbrasil.com.br/wp-content/uploads/2017/03/Distancia-focal.jpg 
O ângulo de visão é a medida que mostra o quanto de uma cena, ou elemento, uma lente pode absorver. A medida é representada em graus e pode ser feita horizontalmente, verticalmente, ou diagonalmente em uma imagem.

Nesse caso, a distância focal é essencial: lentes com distância focal mais curta são capazes de capturar mais de uma cena em apenas uma fotografia. Enquanto isso, distâncias focais mais longas oferecem uma visão mais limitada. É claro que você pode afastar a câmera da cena para trazer mais elementos à fotografia, ou se aproximar do modelo para preencher mais o quadro da imagem. Outra opção é ficar no mesmo lugar e usar o zoom da lente para aproximar, ou afastar algo do quadro. Independente da sua escolha, o ângulo de visão para a distância focal da sua lente fotográfica não vai mudar.

\section{7.}

\section{A perspectiva e a ilusão de ótica na fotografia}

A perspectiva se refere à dimensão dos objetos e ao relacionamento espacial que há entre eles, além da posição do olho humano em relação aos objetos da imagem. Já o ângulo marca a localização específica de onde uma foto foi tirada. De modo geral, a perspectiva traz profundidade à imagem, enquanto o ângulo modifica sua localização.

Ao fotografar exatamente a mesma paisagem de diferentes ângulos e perspectivas, é possível obter resultados totalmente diferentes, o que mostra um pouco da riqueza que existe na arte de fotografar.

Vale ressaltar que a fotografia é a representação bidimensional de um mundo tridimensional, porém, com o uso da perspectiva é possível simular uma profundidade na imagem que é entendida pelo cérebro como um espaço 3D.

Para compor uma fotografia existem elementos importantes, tais como linha do horizonte, que é a linha imaginária que representa o nível dos olhos do observador; ponto de vista, que é o ponto de convergência do olhar do observador e é definido traçando uma linha perpendicular à linha do horizonte no local onde se encontra o observador; ponto de fuga, que é para onde convergem todas as linhas de fuga dos elementos da imagem; linhas de fuga, que são linhas imaginárias, traçadas na imagem, que convergem para o ponto de fuga. É a trajetória des- 
sas linhas rumo ao ponto de fuga que proporcionam a sensação de profundidade da imagem.

Dependendo da localização, altura e posição, pode-se capturar uma mesma cena (ou objeto) de diferentes ângulos de visão. A câmera pode estar na mesma altura, abaixo, acima, mais distante ou mais próximo do objeto. O que se deve levar em conta é a impressão causada por aquela imagem, dependendo do ângulo pelo qual ela foi capturada.

Se a máquina fotografa de baixo para cima, haverá uma impressão de que o objeto é maior, já o contrário, quando a imagem é fotografada de cima para baixo, temos a nítida impressão de que é menor. O contexto, contudo, influenciará nestas impressões.

Tendo em vista que a fotografia é uma imagem bidimensional, podemos nos utilizar da perspectiva para simular uma terceira dimensão, ou seja, a profundidade dos elementos contidos na imagem. A perspectiva evidencia ou esconde linhas e formas, fazendo com que se criem efeitos de ilusão de ótica na fotografia.

Fotografando um pequeno objeto bem próximo da câmera, ao lado de um grande objeto, porém distante, a imagem pode dar a ilusão de que os dois são do mesmo tamanho. Esta perspectiva pode, contudo, mudar, dependendo do posicionamento do fotógrafo em relação a estes mesmos objetos.

As imagens em que se usam a ilusão de perspectiva não precisam de montagens difíceis em softwares de edição de imagens. Elas precisam apenas da técnica da perspectiva forçada, que usa a distância relativa dos elementos da fotografia para criar efeitos curiosos. Essa técnica pode ser feita com qualquer objeto e pessoa, o que faz com que o fotógrafo possa explorar ao máximo a sua criatividade. Vamos apresentar algumas opções de ilusões de óticas que podem ser impressas nas fotografias:

- A desproporção dos objetos - uma das maneiras mais usadas para criar a ilusão de perspectiva é mudar o tamanho dos objetos, ou seja, deixá-los, na imagem, muito maiores, ou menores do que eles são na vida real.

- Elementos enormes, elementos pequenos - Fazer com que algum elemento da fotografia fique muito grande e que outro fique muito pequeno é o tipo 
mais comum de ilusão de perspectiva. Para fazer esse tipo de imagem, o fotógrafo precisa de pelo menos duas pessoas e um local aberto, de preferência grande.

- Criar confusão mental - Um pouco diferente das imagens divertidas, são aquelas que usam da ilusão de perspectiva para criar confusão mental em quem as vê. Essa fotografia possui elementos como ângulos distorcidos e imagem rotacionada, sempre passando a impressão de dúvida e confusão em relação a como a imagem foi registrada pela câmera.

A seguir temos várias exemplos de fotografias usando ilusão de ótica (vide figuras 42 a 46).

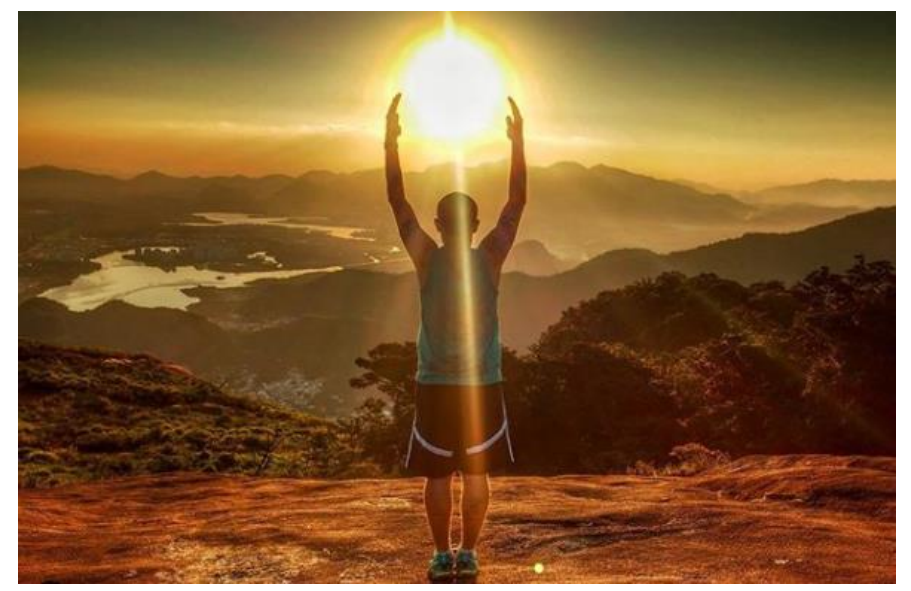

Figura 42 - Ilusão de ótica Fonte: fotografia pessoal do autor

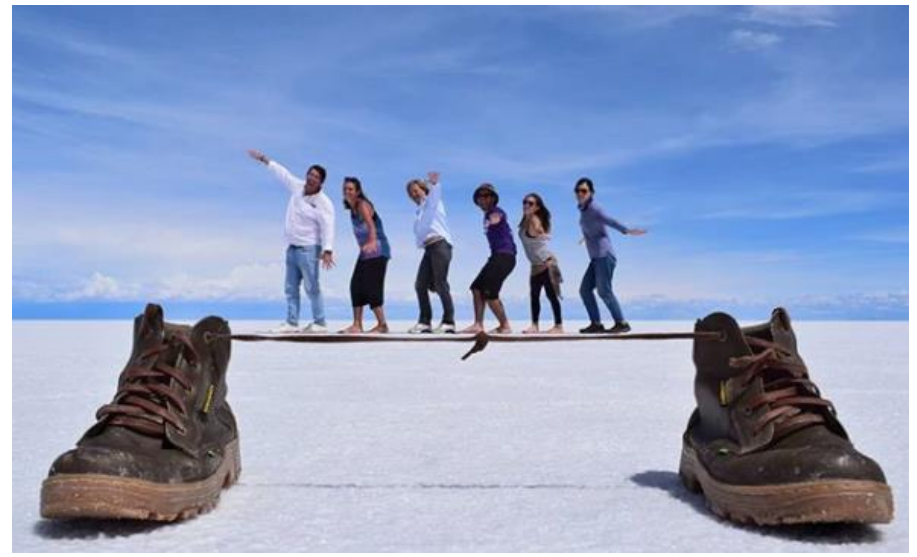

Figura 43 - Ilusão de ótica Fonte: fotografia pessoal do autor 


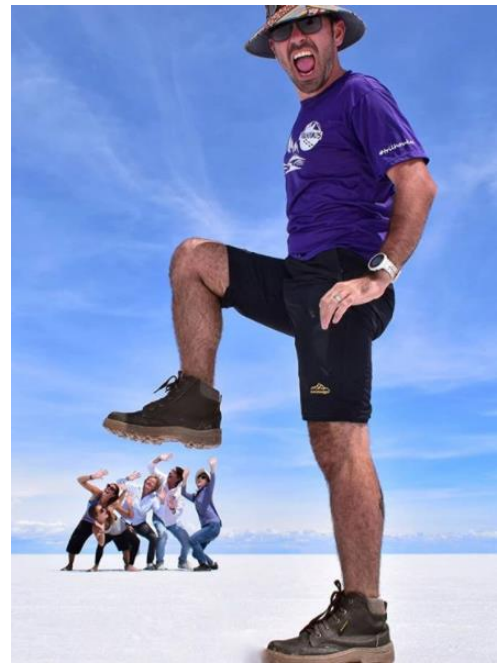

Figura 44 - Ilusão de ótica Fonte: fotografia pessoal do autor

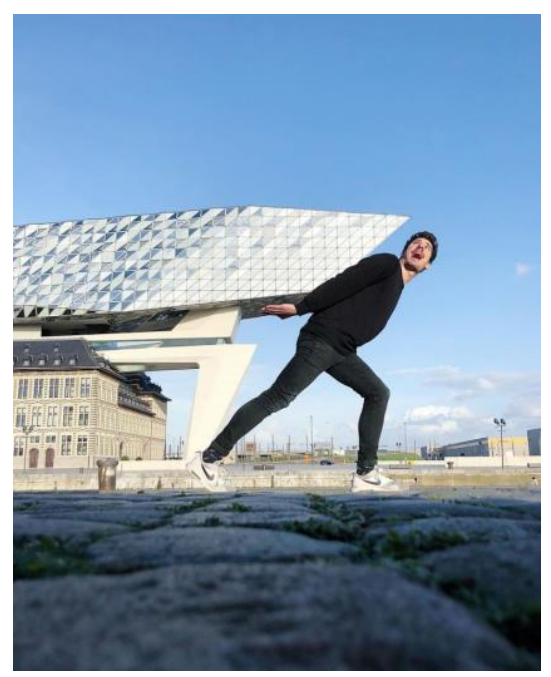

Figura 45 - Ilusão de ótica Fonte

https://thumbs.web.sapo.io/?W=800\&H=0\&delay_optim=1\&epic=MjZh5A5ooZqPUqkeqNxMrR DKiP1N/IVINQ2buOwM3YrqA1MjP0m8oP3RI9Fvvez8H0IJ7myt4/sxIWR7OEvqx8oMXM73m vQ1WLppRWB4IPBgUYc

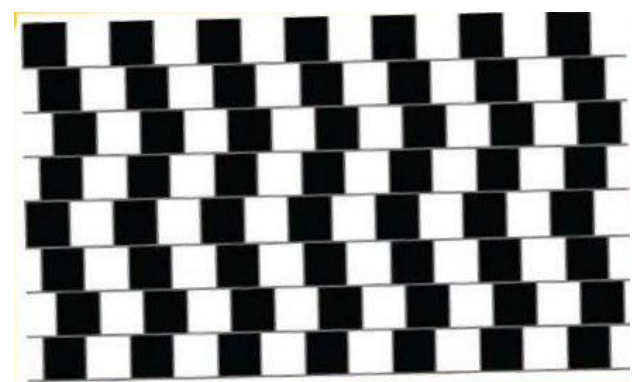

Figura 46 - Ilusão de ótica Fonte:

http://www.portaldaoftalmologia.com.br/cache/multithumb_thumbs/b_300_0_16777215_00_https hypescience.com_wp-content uploads 2018 02 foto-ilusao-otica-4-838x629.jpg 


\section{4 \\ Pesquisa de Campo}

\section{1 - Apresentação do projeto aos alunos}

A pesquisa de campo sobre o uso da Matemática na fotografia foi realizada com alunos das turmas de projeto Carioca I e Carioca II da Escola Municipal Professor Jorge Luiz Itaboraí de Almeida, localizada a Rua Alexis Carrel, s/n - Guaratiba, zona oeste do Rio de Janeiro, no período de $1^{\text {o }}$ de setembro de 2020 a 30 de outubro de 2020. A direção da Unidade Escolar é composta pelas professoras: Jane Correa Brandão, que ocupa a função de diretora, Alita Soares da Costa, que ocupa a função de diretora adjunta e a professora Aline Valadão Vieira Gualda Pereira, que ocupa a função de Coordenadora Pedagógica.

As turmas que participaram do trabalho possuem, respectivamente, 28 alunos na turma do projeto Carioca I (7101), sendo 20 meninos e 8 meninas, e 33 alunos na turma do projeto Carioca II (7102), sendo 24 meninos e 9 meninas. Como 37 alunos não possuem acesso a internet e não possuem celular, não puderam participar da pesquisa. Ou seja, a pesquisa foi realizada com 24 alunos.

O objetivo dessa atividade é descobrir se alunos conseguem perceber que existe Matemática presente na fotografia e que ela ajuda a obter resultados satisfatórios na imagem capturada.

Como durante o período da pesquisa o mundo estava passando por uma pandemia e as aulas presenciais estavam suspensas, o trabalho foi realizado de forma online., o que dificultou a realização de uma pesquisa de campo com mais riqueza de detalhes.

Eu gravei uma videoaula, onde comecei com um resumo da história da fotografia, explicando o que é fotografia e como ocorreu o seu surgimento, apresentei, também, as primeiras imagens registradas (preto/branco e colorida). Em seguida, falei do avanço tecnológico no mundo e, com isso, como as máquinas fotográficas foram modificando (para isso usei fotos de vários modelos antigos até chegar aos dias atuais). Além disso, expliquei o que é uma câmera fotográfica e que ela funciona como se fosse um olho humano. E para encerar esse primeiro momento, apresentei todos os componentes de uma câmera fotográfica. Na segunda parte da videoaula, mostrei como a matemática está presente nas fotografi 
as, pois ela aparece com as frações na velocidade do obturador (apresentei as fotos da cachoeira e do cata-vento). Logo depois, falei sobre a proporção áurea e a sequência de Fibonacci mostrando como usar o retângulo de ouro para obter uma fotografia mais harmoniosa. Em seguida, falei sobre a regra do terço, que pode ser utilizada para conseguir melhor composição da fotografia e, assim, agradar o espectador. Foi explicado como usar a regra dos terços com algumas fotos. Para encerrar, falei sobre a perspectiva e como usá-la para criar a ilusão de ótica na fotografia. Após todas essas explicações, solicitei que os alunos capturassem três fotos: uma usando proporção áurea, uma usando a regra dos terços e uma usando ilusão de ótica. Em seguida, eles deveriam responder o questionário abaixo, que foi disponibilizado também de forma online, através do seguinte link: https://docs.google.com/forms/d/e/1FAIpQLScqgudd9_3rIpX2qs5z5DNcWn9yJPdPN1ulx43bvQv6vcNNw/viewform

Questionário

1 - Nome do aluno:

2 - Turma:

3 - Você costuma fotografar momentos do seu dia a dia?

4 - Você teve dificuldades para compreender os conteúdos explicados na videoaula?

5 - Você tem noção de qual parte da Matemática utilizou para fotografar usando a proporção áurea e a regra dos terços?

6 - Qual das três fotografias você encontrou mais dificuldade para conseguir atingir uma boa fotografia?

7 - Depois da explicação da videoaula, você acha que a Matemática é importante para realizar uma boa fotografia?

8 - Qual foi a parte da Matemática que você achou fundamental para melhorar a fotografia?

9 - Deixe um pequeno resumo sobre o que achou do trabalho.

\section{2.}

\section{Resultados}

Após análise das respostas dos 24 alunos que participaram da pesquisa, podemos afirmar que $79,2 \%$ dos alunos entrevistados possuem o hábito de fotografar momentos do seu dia a dia e 20,8\% não possuem esse hábito, o que comprova que a fotografia faz parte do cotidiano do ser humano atualmente.

A segunda pergunta era sobre o entendimento e compreensão da videoaula preparada para que os alunos pudessem entender o trabalho. De acordo com as 
respostas, tivemos $41,7 \%$ não tiveram dificuldades para entender e 58,3\% tiverem algum tipo de dificuldade para entender o conteúdo ministrado.

Em seguida, foi perguntado ao aluno se tinha noção de qual parte da Matemática utilizou para fotografar usando a proporção áurea e a regra dos terços e somente $33,3 \%$ dos alunos responderam positivamente, contra $66,7 \%$ de respostas negativas, demonstrando claramente que a maioria não sabe qual parte da Matemática é utilizada para a proporção áurea e para a regra dos terços, que é a proporcionalidade.

Posteriormente, os alunos tiveram que responder qual das três fotografias (ilusão de ótica, proporção áurea e regra dos terços) encontraram mais dificuldades para obter uma boa foto. O resultado foi: ilusão de ótica: $20,8 \%$, proporção áurea: $66,7 \%$ e regra dos terços: $12,5 \%$.

A próxima pergunta era se depois da explicação da videoaula, os alunos achavam que a Matemática é importante para realizar uma boa fotografia e o resultado foi unânime, $100 \%$ alunos responderam positivamente.

E para finalizar foi perguntado qual parte da Matemática é mais importante para obter uma boa composição fotográfica. O resultado foi: fração 8,3\%, noções de área 16,7\%, proporção 20,8\%, sequência de Fibonnaci 4,1\% e perspectiva $50,1 \%$. Ou seja, mais da metade dos alunos entrevistados acham que a principal parte da Matemática para capturar uma boa imagem é a perspectiva.

Com esses resultados, podemos concluir que a Matemática é importante para conseguir obter um bom resultado nas fotografias e que o tema deve ser trabalhado em sala de aula, enriquecendo assim o currículo. Vale ressaltar que é um assunto atrativo para os alunos e os professores podem usá-lo para explicação dos conteúdos envolvidos e, assim, conseguir atingir tópicos que na maioria das vezes não prendem tanto a atenção dos alunos.

\section{3. \\ Fotografias dos alunos}

Seguem abaixo algumas das diversas fotografias capturadas pelos alunos durante a pesquisa de campo (vide figuras 47 a 57). Vale ressaltar que foram selecionadas algumas, uma vez que eram muitas fotografias. 


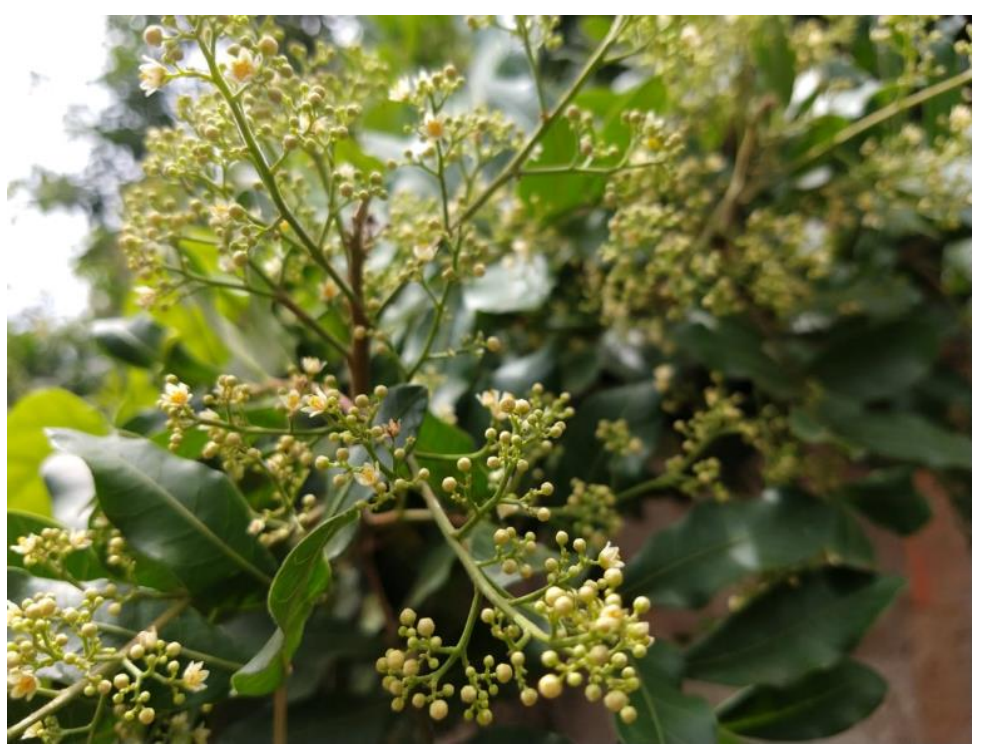

Figura 47 - Foto do aluno A da turma 7102

Fonte: foto enviada pelo aluno através de aplicativo de mensagem

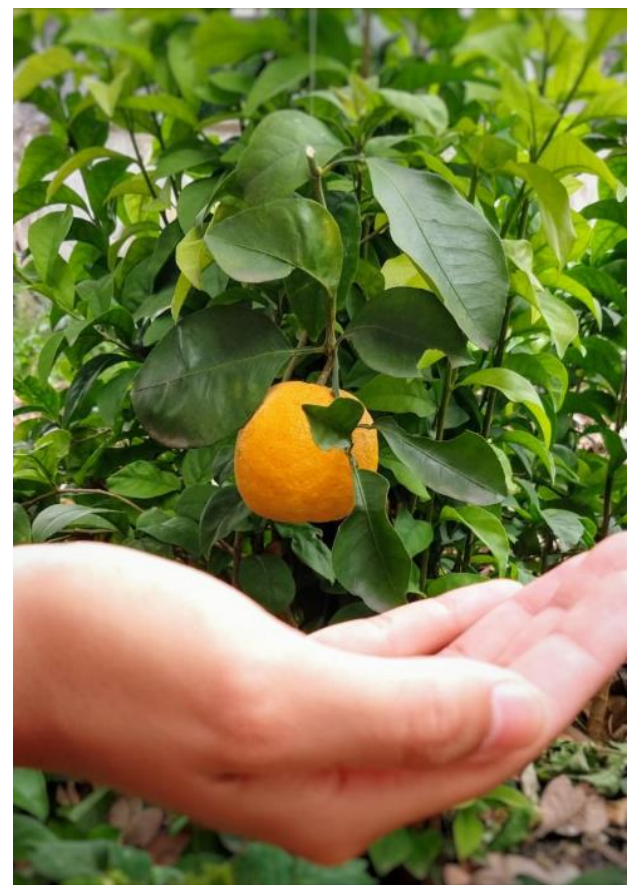

Figura 48 - Foto do aluno B da turma 7102

Fonte: foto enviada pelo aluno através de aplicativo de mensagem 


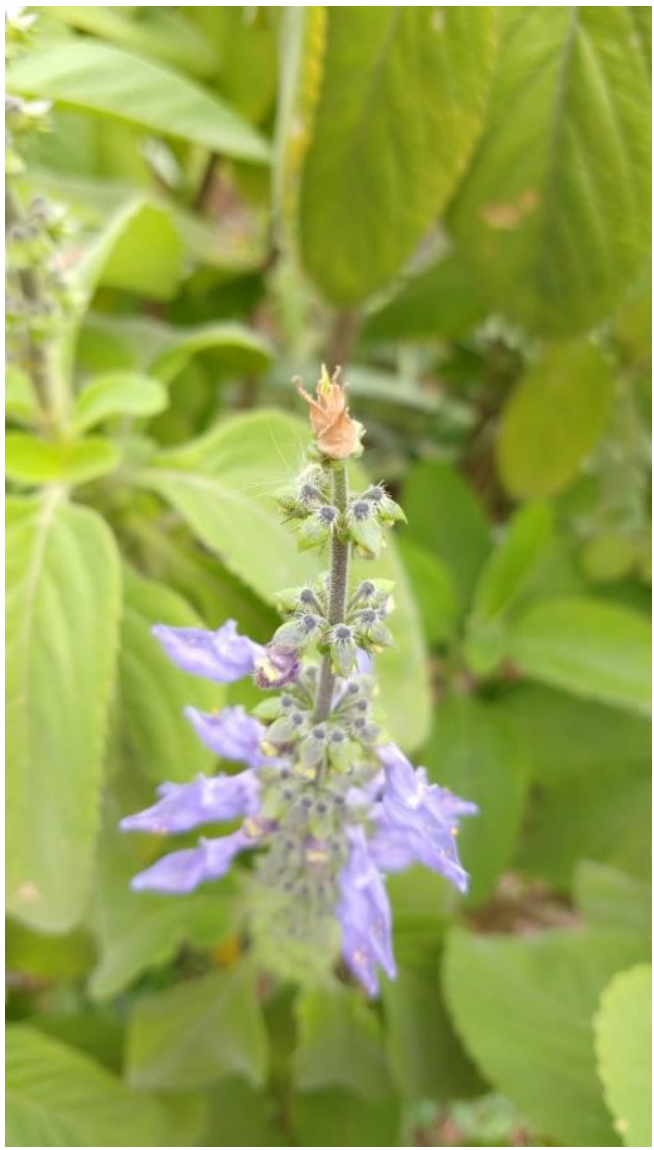

Figura 49 - Foto do aluno $\mathrm{C}$ da turma 7102

Fonte: foto enviada pelo aluno através de aplicativo de mensagem

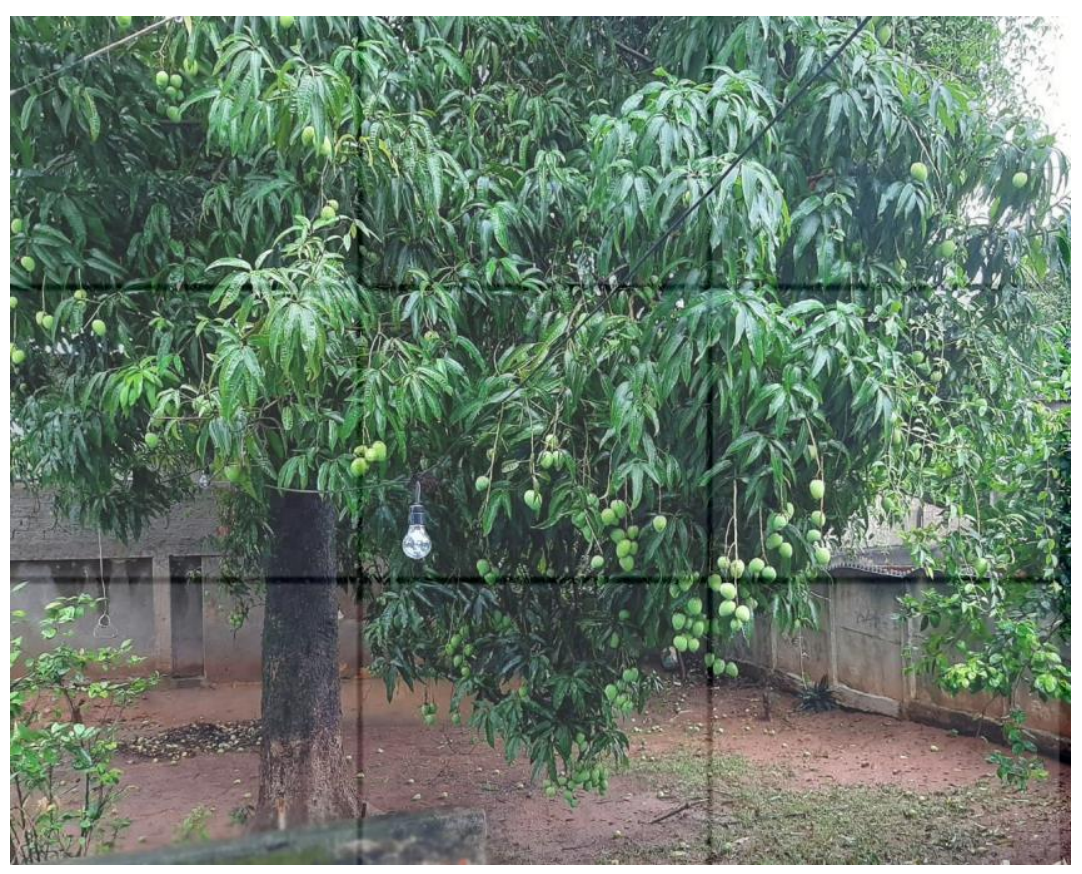

Figura 50 - Foto do aluno D da turma 7101

Fonte: foto enviada pelo aluno através de aplicativo de mensagem 


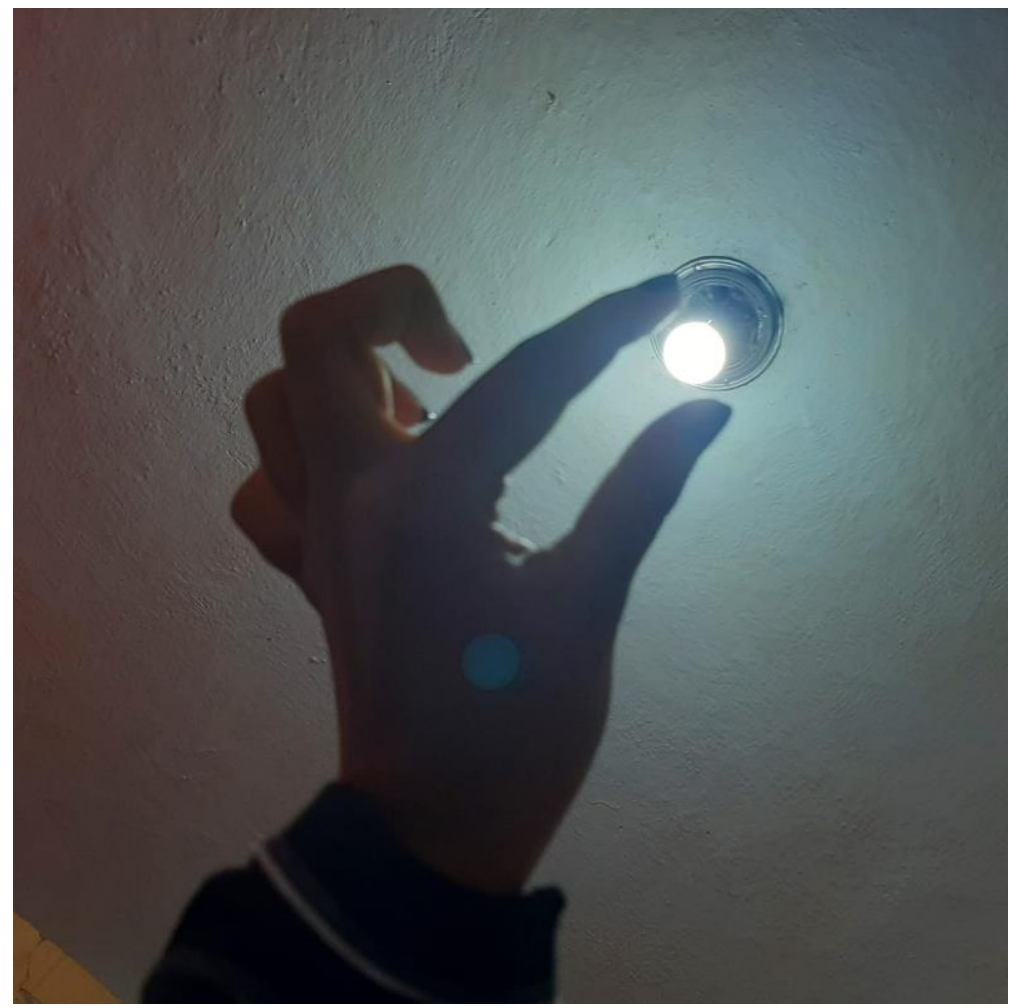

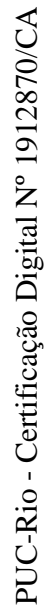

Figura 51 - Foto do aluno E da turma 7102

Fonte: foto enviada pelo aluno através de aplicativo de mensagem

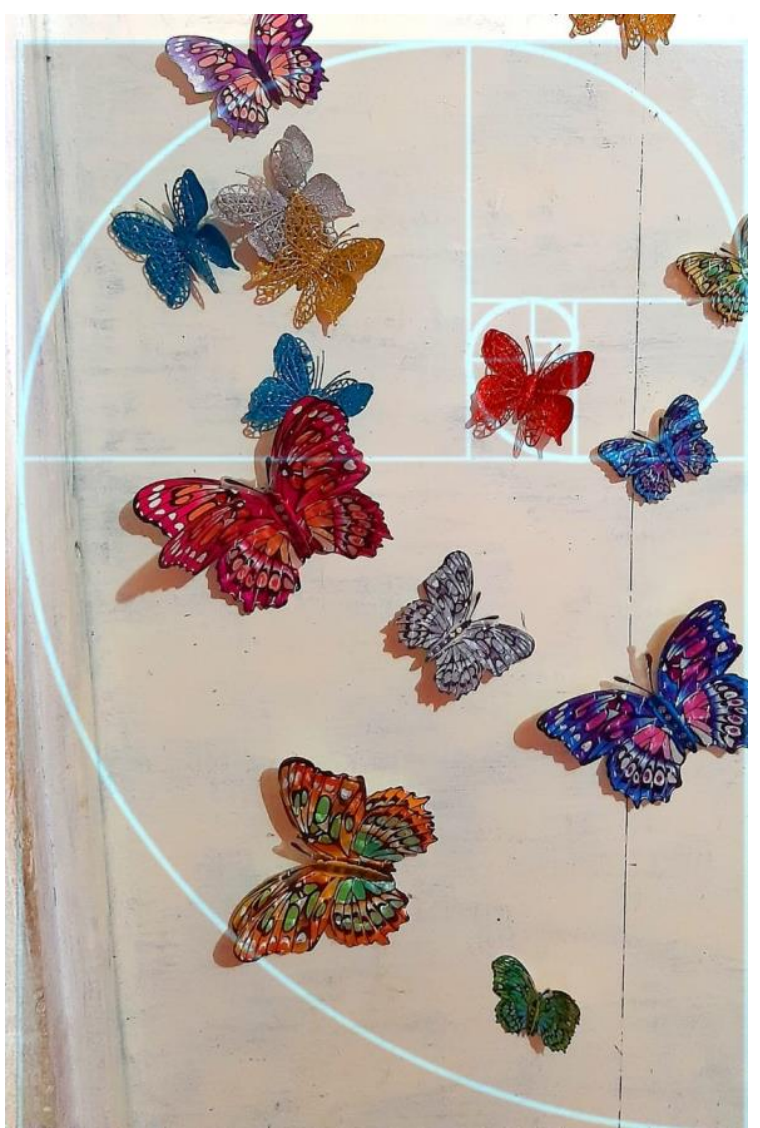

Figura 52 - Foto do aluno F da turma 7102

Fonte: foto enviada pelo aluno através de aplicativo de mensagem 


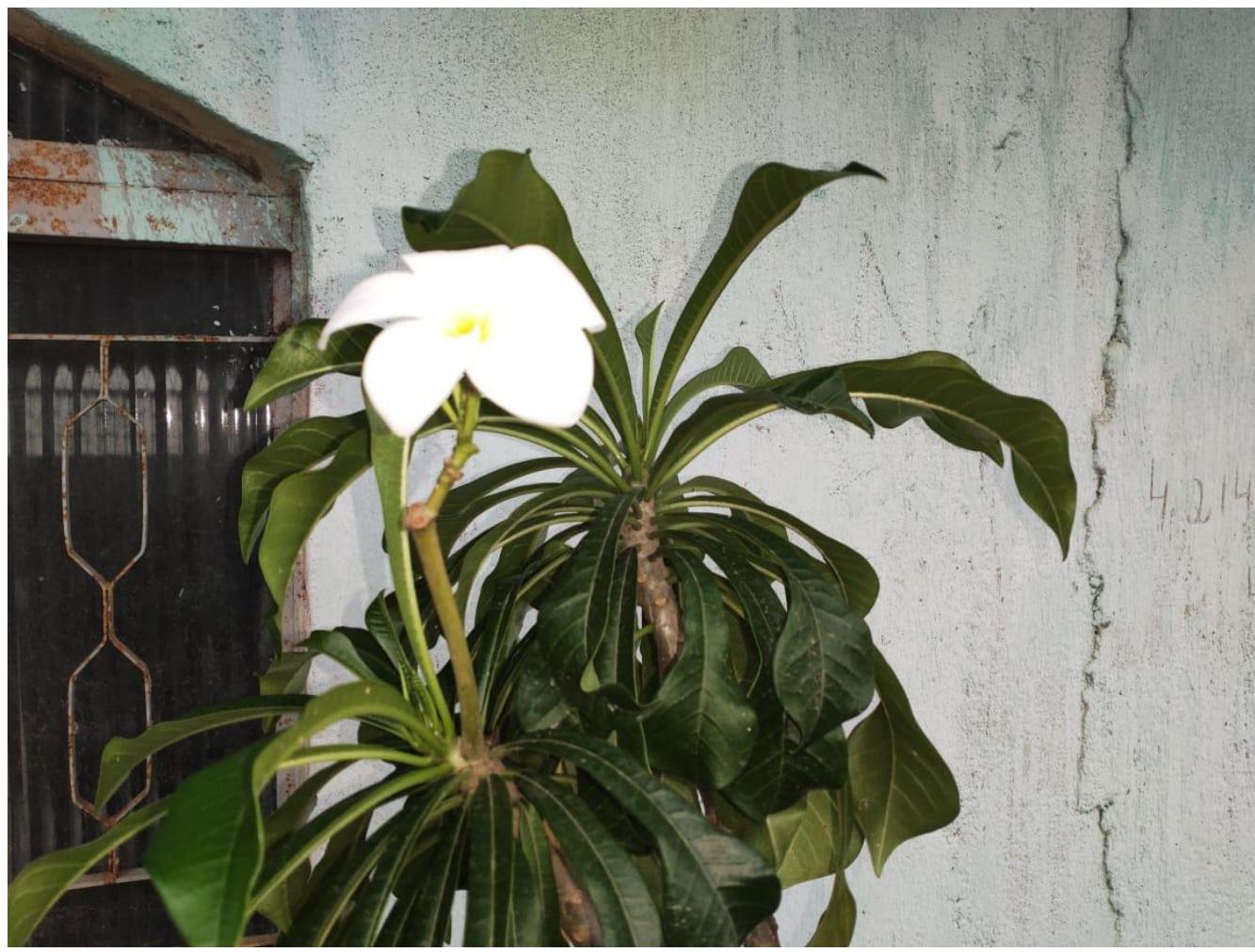

Figura 53 - Foto do aluno G da turma 1903

Fonte: foto enviada pelo aluno através de aplicativo de mensagem

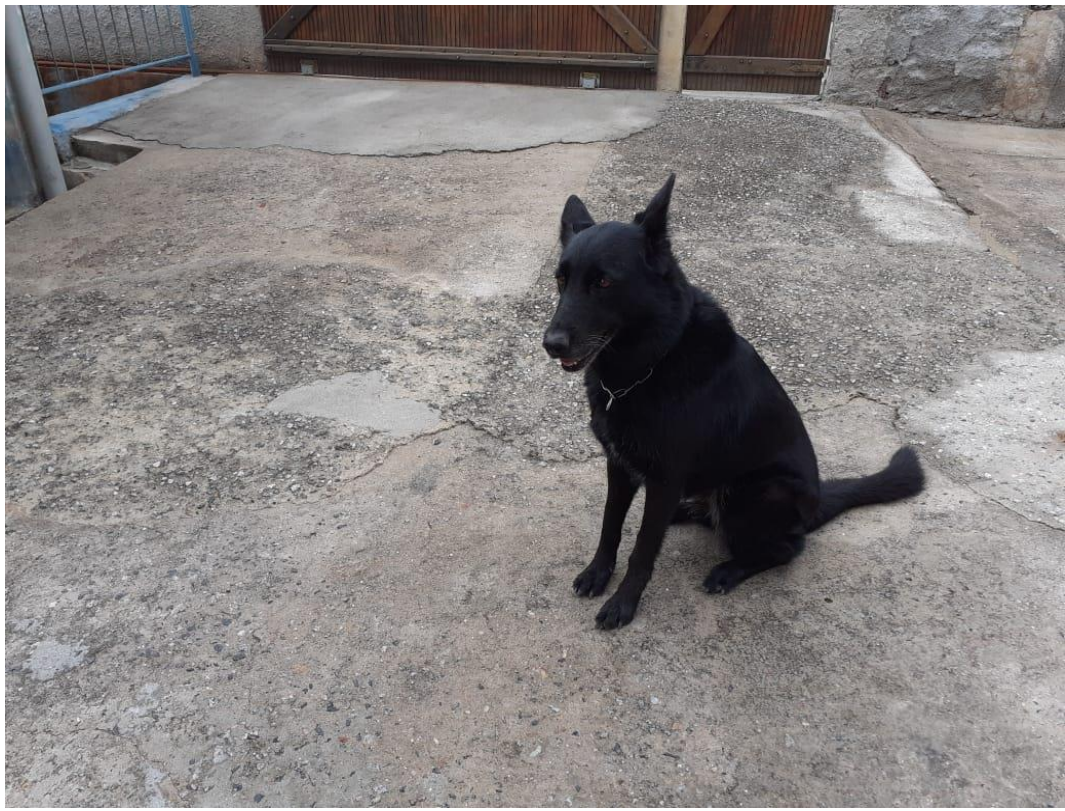

Figura 54 - Foto do aluno H da turma 7101

Fonte: foto enviada pelo aluno através de aplicativo de mensagem 


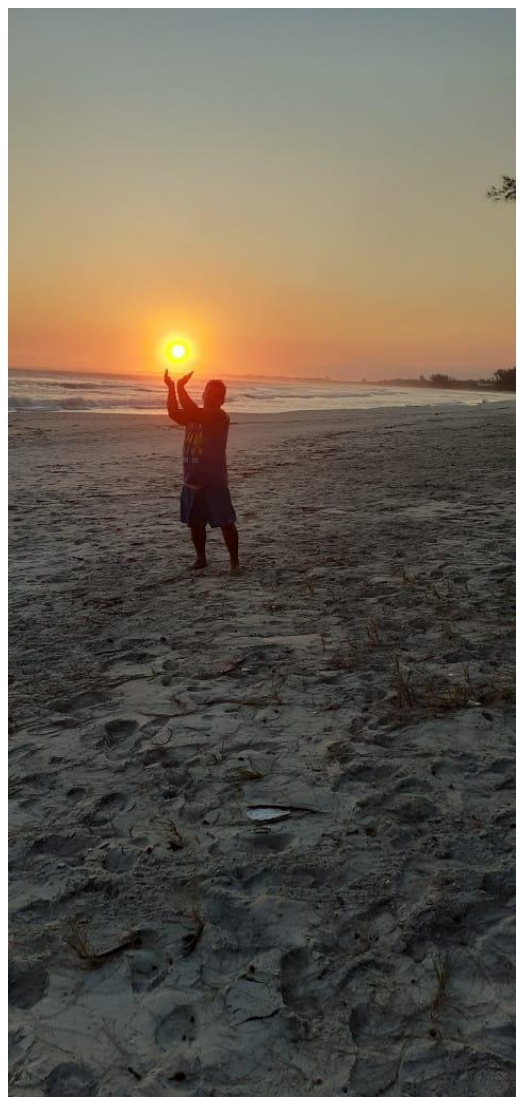

Figura 55 - Foto do aluno I da turma 1903

Fonte: foto enviada pelo aluno através de aplicativo de mensagem

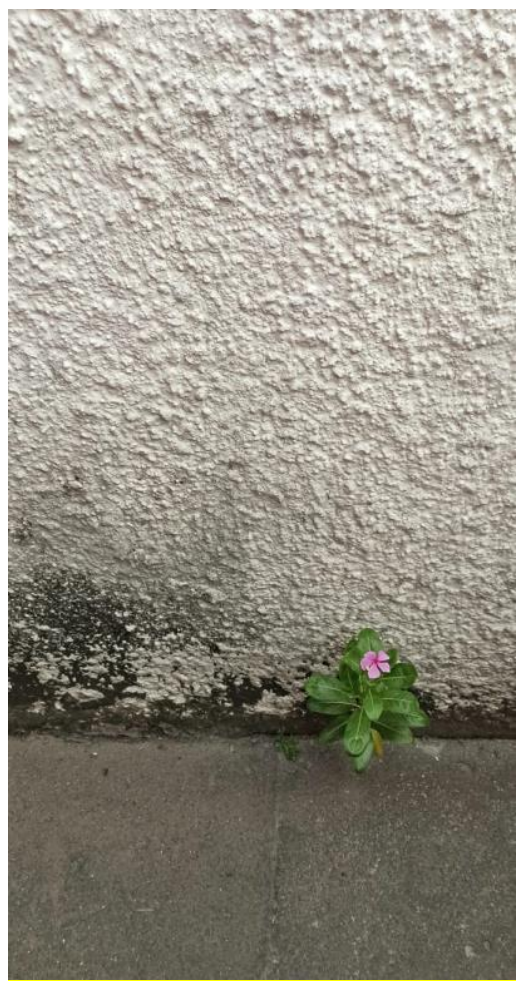

Figura 56 - Foto do aluno J da turma 7101

Fonte: foto enviada pelo aluno através de aplicativo de mensagem 


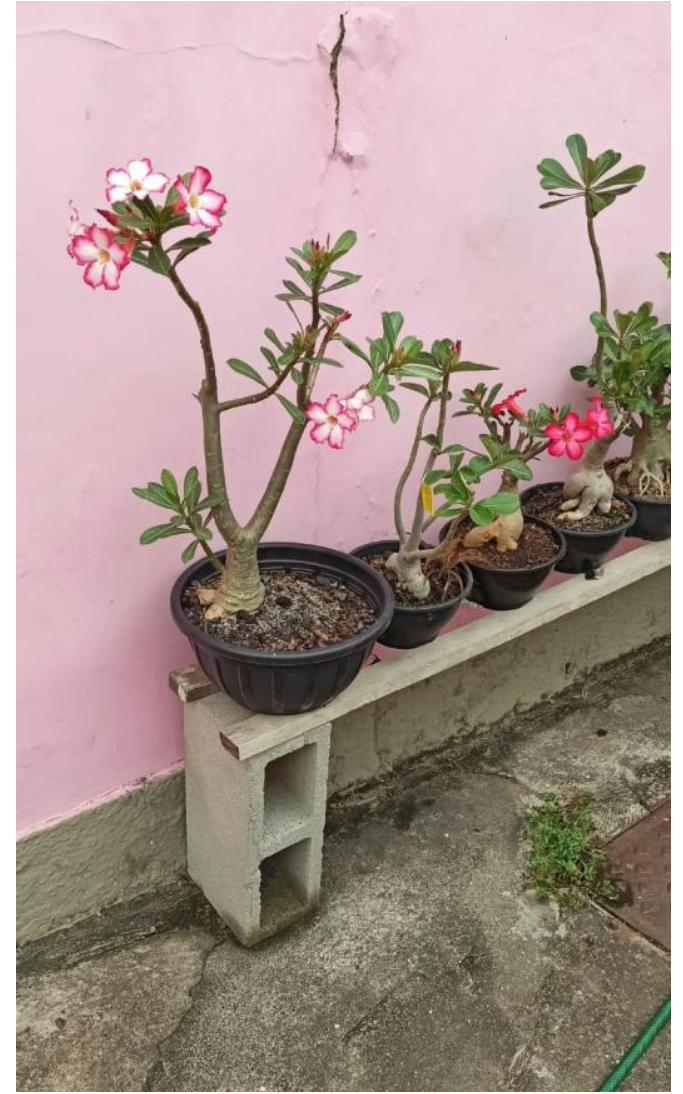

Figura 57 - Foto do aluno K da turma 7201

Fonte: foto enviada pelo aluno através de aplicativo de mensagem 


\section{5 \\ Considerações finais}

O objetivo da pesquisa foi atingido, pois os alunos conseguiram detectar a Matemática presente na fotografia e entender a importância de estudar os conteúdos envolvidos para que consigam obter uma fotografia de boa qualidade. Como a fotografia está presente no cotidiano do ser humano, principalmente dos jovens, é uma oportunidade de trabalhar alguns conteúdos matemáticos que são necessários para a fotografia.

Com isso, podemos deixar um questionamento para professores de Matemática: Porque não inovar nas suas aulas, trazendo a Matemática para a parte concreta e saindo do abstrato? Os alunos precisam ver onde a Matemática será usada e, assim, despertar o interesse pelo conteúdo.

Foi excelente preparar este trabalho, pois é sempre bom aprender novos conhecimentos e estar em contato, mesmo que de forma online, com alunos, vivenciando as dúvidas e novos aprendizados. 
6

\section{Referências Bibliográficas}

GARCIA, G. J. Sensoriamento Remoto - Princípios e Interpretação de Imagens. Editora: NOBEL, São Paulo. 1982

KOSSOY, B. Hercules Florence - A descoberta isolada de fotografia no Brasil. 1980.

BERLINGHOFF, W.; GOUVÊA, F. Q. A Matemática através dos tempos. 2.ed. São Paulo: Blucher, 2008.

MENDES, B. Câmeras fotográficas antigas \#3: 1900-1923.

Disponível em:

$<$ http://obviousmag.org/archives/2010/02/cameras fotograficas antigas 3 1900-1923.html> Acesso em 13 ago. 2020.

ARAUJO, A. Velocidade do obturador.

Disponível em:

<https://www.infoescola.com/fotografia/velocidade-do-obturador/> Acesso em 3 set. 2020.

BEZERRA, J. História da fotografia.

Disponível em:

$<$ https://www.todamateria.com.br/historia-da-fotografia/> Acesso em 8 set. 2020.

VIERO, E. O que é regra dos terços: um guia para iniciantes.

Disponível em:

$<$ https://www.eduardo-monica.com/new-blog/regras-dos-tercos $>$ Acesso em 19 ago. 2020.

KILHIAN, K. A matemática da câmera fotográfica. Disponível em: <https://www.obaricentrodamente.com/2011/10/matematica-da-camerafotografica.html>. Acesso em 19 ago. 2020

MOREIRA, A. O uso do golden ratio na fotografia. Disponível em: $<$ https://medium.com/@andrebmoreira93/o-uso-do-golden-ratio-nafotografia-17822e400ce4> Acesso em 21 ago. 2020

WANDERLEY, A. Os 180 anos do invento do daguerreótipo - Pequeno histórico e sua chegada no Brasil. Disponível em:

<http://brasilianafotografica.bn.br/?p=16443> Acesso em 25 ago. 2020 